PNL-8122

UC-903

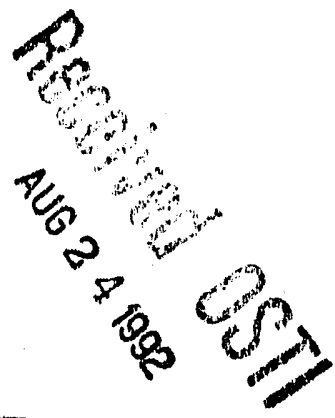

\title{
Water-Table Elevations \\ on the Hanford Site and \\ Outlying Areas, 1991
}

D. R. Newcomer

K. D. Pohlod

I. P. McDonald

August 1992

Prepared for the U.S. Department of Energy under Contract DE-AC06-76RLO 1830

Pacific Northwest Laboratory

Operated for the U.S. Department of Energy

by Battelle Memorial Institute 


\title{
DISCLAIMER
}

This report was prepared as an account of work sponsored by an agency of the Uniled States Government. Neither the United States Government nor any agency thereof, nor Batlelle Memorial Institute, nor any of their employees, makes any warranty, expressed or implied, or assumes any legalliability or responsibility for the accurac $y$, completeness, or usefulness of any information, apparatus, product, or process disclosed, or represents that its use would not infringe privately owned rights. Reference herein to any specific commercial product, process, or service by trade name, trademark, manufacturer, or otherwise does not necessarily constitute or imply its endorsernent, recommendation, or favoring by the United States Government or any agency thereof, or Baltelle Memorial Institute. The views and opinions of authors expressed herein do not necessarily slate or reflect those of the United States Government or any agency i... sol.

\author{
PACIFIC NORTHWEST LABORATORY \\ operated by \\ BATTELLE MEMORIAL INSTITUTE \\ for the \\ UNITED STATES DEPARTMENT OF ENERCY \\ under Contract DE-ACO6-76RLO 1830
}

Printed in the Uniled Slates of America

Avallable to DOE and DOE contractors from the

Office of Scientific and Technical Information, P.O. Box 62, Oak Ridge, TN 37831; prices available from (615) 576-8401. FTS 626-8401.

Available to the public from the National Technical information Service, U.S. Depariment of Commerce, 5245 Port Royal Rd., Springfield, VA 22161. 
PNI-8122

DE92 019704

WATER-TABLE ELEVATIONS ON THE HANFORD SITE

AND OUTLYING AREAS, 1991

D. R. Newcomer

K. D. Pohlod

J. P. McDonald

August 1992

Prepared for the U.S. Department of Energy under Contract DE-AC06-76RLO 1830

Pacific Northwest Laboratory

Richland, Washington 99352 


\section{SUMMARY}

The Pacific Northwest Laboratory prepared water-table maps of the U.S. Department of Energy's Hanford Site for June-August 1991 from water-level elevations measured in 359 wells across the Hanford Site and outlying areas. The greatesi changes in the elevation of the water table at Hanford occurred beneath the decommissioned U Pond, the 200-East Area, B Pond, the 100-N Area, the 1100 and 3000 Areas, the Cold Creek valley, and adjacent to the Columbia River.

The elevation of the water table beneath the 100-N Area declined as much as $0.34 \mathrm{~m}(1.1 \mathrm{ft})$ between December 1990 and December 1991. This decline in the water table is primarily the result of decreasing volumes of wastewater discharged to waste disposal facilities in the 100-N Area.

Water levels beneath the 200 Areas, including the water levels beneath the decommissioned $U$ Pond, decreased as much as $0.21 \mathrm{~m}(0.7 \mathrm{ft})$ between December 1990 and December 1991, primarily in response to decreasing wastewater discharged to various ponds, cribs, and trenches in the 200 Areas and continued dissipation of the ground-water mound beneath much of the 200-Wes $i$ Area.

The elevation of the ground-water mound beneath $B$ Pond, which continues to receive wastewater, declined as much as $0.30 \mathrm{~m}(1.0 \mathrm{ft})$ between December 1990 and December 1991.

In the 1100 and 3000 Areas, the elevation of the water table responded to pumping and recharge by the city of Richland's well field and ground-water recharge basin system and to recharge from irrigation practices west of the 1100 Area.

Water levels in the Cold Creek Valley declined steadily during 1991 , with a change of approximately $0.49 \mathrm{~m}(1.6 \mathrm{ft})$ between March 1991, when monitoring began, and December 1991. The observed change is associated with irrigation practices in the upper Cold Creek Valley, but water levels may also be responding to wastewater disposal practices in the 200 Areas. 
The water table adjacent to the Columbia River along the Hanford Reach continues to respond significantly to fluctuations in river stage.

Water levels measured from unconfined aquifer wells north and east of the Columbia River in 1991 indicate that the primary source of recharge is from irrigation practices. The configuration of the water table is controlled by the configuration of the basalt surface, hydrogeologic characteristics of the unconfined aquifer sediments, and topographic features. 


\section{CONTENTS}

SUMMARY .................................... i i

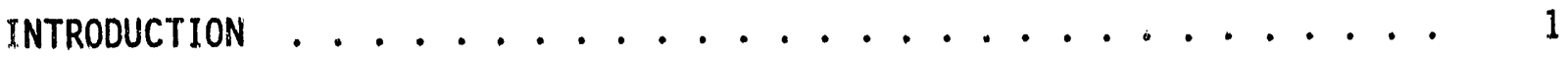

GEOLOGY .......................... 4

HYDROLOGY .............................. 5

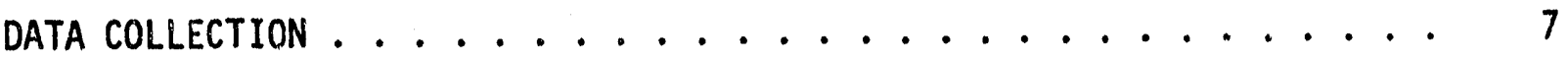

RESULTS .............................. 13

HANFORD SITE WATER-TABLE FEATURES . . . . . . . . . . . . 15

CHANGES IN THE HANFORD SITE WATER TABLE DURING $1991 \ldots 17$

200 AREAS ......................... 17

216-B-3 Pond ...................... 17

Decommissioned U Pond ................ 19

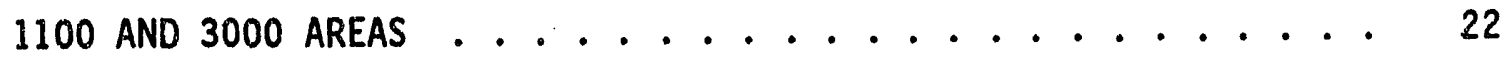

UPPER COLD CREEK VALLEY ................... . . 28

HANFORD REACH .................... 30

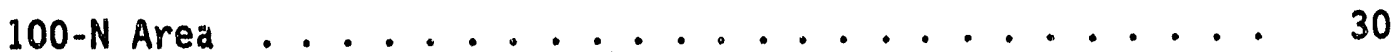

300 Area .................... . . . 32

WATER-TABLE FEATURES EAST AND NORTH OF THE COLUMBIA RIVER . . . . . . . 37

SUMMARY AND CONCLUSIONS ............................ 43

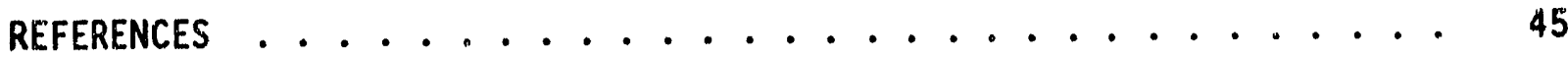

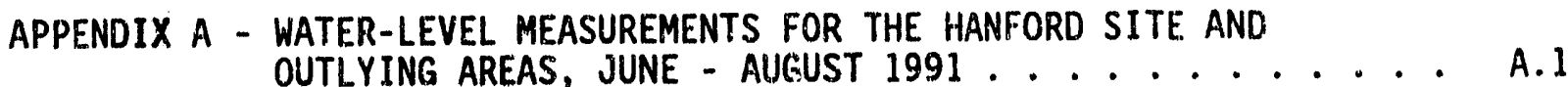

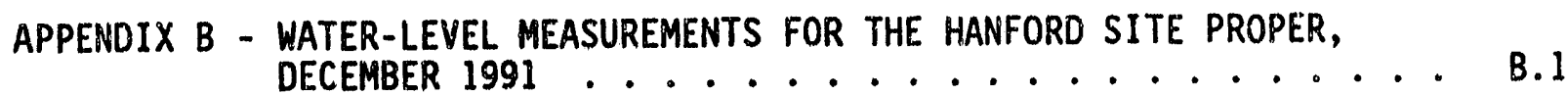

APPENDIX C - WATER-LEVEL MEASUREMENTS AT SPECIFIC HANFORD SITE AREAS,
JUNE $1991 . \ldots \ldots . \ldots$ 


\section{FIGURES}

1 Hanford Site Location Map ................ 3

2 Index Map, for Location of Wells ............. 9

3 Water-Table Map Beneath 216-B-3 Pond for June 1991 . . . . . . . 18

4 Hydrograph of Wells 699-39-39, 699-40-39, 699-41-40, and $699-42-40 \mathrm{~B} \ldots \ldots . \ldots 20$

5 Water-Tabie Map of the Area Beneath the Decommissioned U Pond in the 200-West Area for June 1991 .......... 21

6 Hydrograph of Wells 299-W10-13, 299-W18-21, and 299-W19-1 . . . 23

7 Water-Table Map Beneath the 300, 1100, and 3000 Areas for June $1991 \ldots \ldots \ldots \ldots . \ldots \ldots$

8 Hydrograph of Well 699-S40-E14 .............. 27

9 Hydrograph of Wells EC-1 and 1199-34-13 .......... 29

10 Hydrograph of Well 699-43-104 . . . . . . . . . . . 31

11 Water-Table Map Beneath the 100-N Area for June $1991 \ldots 33$

12 Hydrograph of Wells 699-81-58, 199-N-27, and 199-N-60 ..... 34

13 Hydrograph of Well 399-8-1 ............... 35

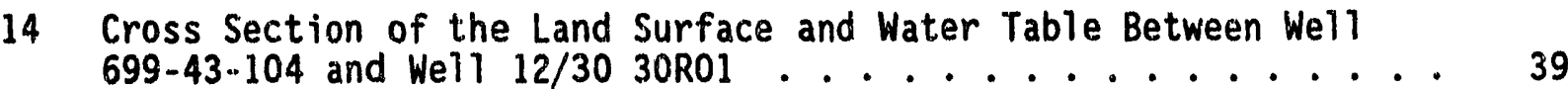

15 Water-Table Map of the Pasco Greenbelt Area .......... 40 Piate 1................ Pocket Inside Back Cover 


\section{INTRODUCTION}

The Site Characterization and Assessment Section, Environmental Sciences Department, of the Pacific Northwest Laboratory (PNL) ${ }^{(a)}$ prepared watertable maps of the Hanford Site and outlying areas for 1991. Production of these maps supports the Ground-Water Environmental Surveillance Program, which is sponsored by the U.S. Department of Energy (DOE).

Water-level measurements can be used to construct a water-table map that represents the elevation of the water-table surface. This map can be used to infer general directions of ground-water flow, particularly in the upper part of the aquifer. Ground water moves from regions of higher water potentials to regions of lower water potentials perpendicular to contours of equal potential, assuming conditions of isotropic hydraulic conductivities. Water-table maps can be used to

- identify recharge and discharge areas

- evaluate the physical influence of wastewater discharges on groundwater flow directions

- identify the potential for water movement between adjacent groundwater and surface water bodies

- represent the horizontal hydraulic gradient, which is required to estimate the average linear velocity of ground-water flow

- improve the design of the water-level monitoring well network

- provide information required to calibrate ground-water flow models.

Production of water-table maps of the Hanford Site in prior years encompassed an area bounded by the Columbia River to the north and east, the anticlinal basalt ridges (i.e., Umtanum Ridge, Yakima Ridge, and Rattlesnake Hills) to the west and southwest, and the Hanford Site boundary between Horn Rapids and the 300 Area to the south. The water-table map for 1991 was extended to include the entire Hanford Site and irrigated agricultural areas north and east of the Columbia River. The map is bounded to the north by the

(a) The Pacific Northwest Laboratory is operated for the U.S. Department of Energy by Battelle Memorial Institute under Contract DE-ACO6-76RLO 1830. 
Saddle Mountains basalt, Jackass Mountain to the east, and the Columbia and Yakima Rivers to the south (see Plate 1). The region covered by the map in Plate 1 was extended so that the hydrology of the Hanford Site could be presented in the context of the regional flow system.

The primary focus of this report is to describe water-level changes observed on the Hanford Site west and south of the Columbia River.

In addition to water levels measured in wells distributed across the Hanford Site, water levels were measured at four specific areas within Hanford. Included are areas around the decommissioned 216-U-10 Pond (U Pond) in the 200-West Area, 216-B-3 Pond (B Pond), 100-N Area, and the southern part of the Hanford Site, which includes the 300, 1100, and 3000 Areas. The locations of these areas, including the adjacent area north and east of the Columbia River, are shown in Figure 1. Water-table maps of these areas are intended to enhance the definition of the water-table configuration beneath wastewater discharge facilities in the 100-N, 200, and 300 Areas, and beneath irrigation lands and municipal facilities beneath the 1100 and 3000 Areas. Aquifer recharge from these facilities may influence ground-water flow.

Water-level measurements and a water-table elevation map of the Hanford Site for June 1990 were presented in Newcomer et a1. (1991). Semiannual water-level measurements and a water-table map of the Separations Areas and 100 Areas of the Hanford Site for December 1990 and June 1991 are presented in Kasza et a1. (1991a) and Kasza et al. (1991b), respectively. Historical water-level data and an evaluation of past changes to the water-table surface are presented in Zimmerman et al. (1986) and Newcomer (1990). Water levels were measured by the United States Geological Survey (USGS) in Grant and Frankl in Counties, located north and east of the Columbia River, for 1986-1989 (Drost et a1. 1989). A regional map of ground-water levels in materials overlying the Columbia River Basalt Group for Spring 1985, including uncanfined aquifer water-level contours for the Pasco Basin, is shown in Bauer et: al. (1985). Brown (1979) presented water-table maps of the Pasco Basin for 


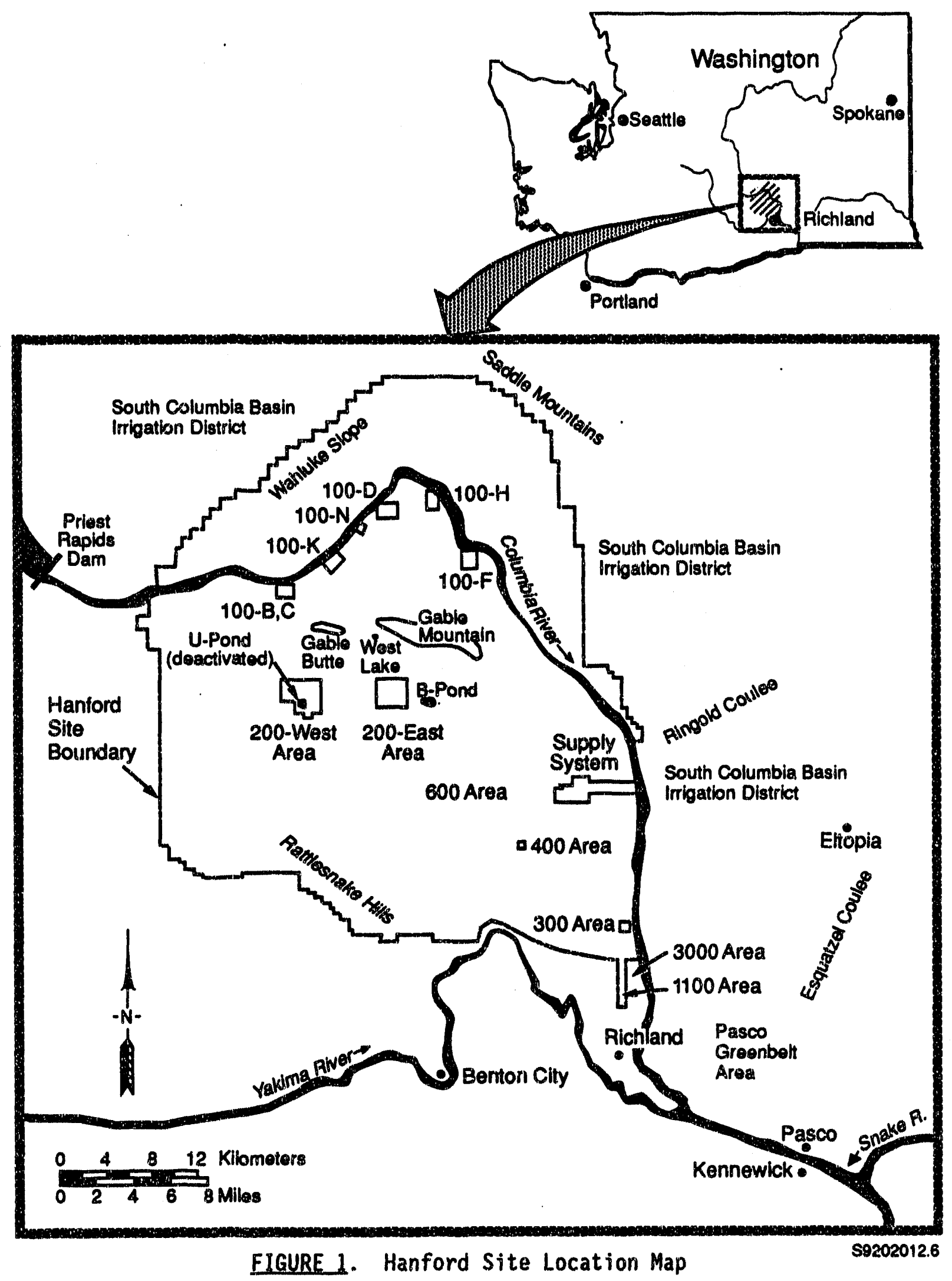


1979, one of the southern half, and characterized the occurrence of unconfined ground water in the eastern part of the Pasco Basin.

Water levels in selected wells completed in the unconfined aquifer on the Hanford Site west and south of the Columbia River are traditionally measured in June and December of each year. The purpose of these measurements is to determine the changes in the configuration of the water table. Changes in the water-table elevation can be used to assess the influence of wastewater disposal on ground-water flow. The U.S. Bureau of Reclamation (USBR) measures water levels quarterly each year in selected observation wells completed in the unconfined aquifer north and east of the Columbia River in Grant, Adams, and Franklin Counties. These measurements are used to monitor water-level changes and drainage patterns associated with recharge from irrigation practices (Walters and Grolier 1960).

The wells used to measure water-levels were chosen based on geologic and hydrologic information available. A brief summary of the geology arid hydrology of the Hanford Site and adjacent areas north and east of the Columbia River follows.

\section{GEOLOGY}

The Hanford Site and the adjacent area north and east of the Columbia River in parts of Grant, Adams, and Franklin Counties lie within the Pasco Basin, one of many topographic and structural basins within the Columbia Plateau. Principal geologic units beneath the area covered in this report include, in ascending order, the Columbia River Basalt Group, the Ringold Formation, and a series of deposits informally referred to as the Hanford formation. These units are covered locally by no more than a few meters of recent alluvial or windblown deposits. 01der geologic units have been deformed into a series of roughly east-west trending folds. A more complete description of the geology of the Hanford Site is contained in reports by DOE (1988), Newcomb et a7. (1972), and Myers et al. (1979). A more complete geologic description of the areas north and east of the Columbia River is covered in Grolier and Bingham (1978). 
HYDROLOGY

Both confined and unconfined aquifers are present beneath the mapped area shown in Plate 1. The confined aquifers lie primarily within the Columbia River basalts. The unconfined aquifer, lies in river and lake deposits of the Ringold Formation and glaciofluvial sediments of the Hanford formation, as well as some more recent alluvial sediments in areas adjacent to the Columbia River (Gephart et a1. 1979). Perched water-table conditions have been encountered in sediments above the unconfined aquifer in the 200-West Area (Airhart 1990) and in irrigated areas east of the Coiumbia River (Brown 1979).

The unconfined aquifer is bounded below by either the basalt surface or, in places, the relatively impervious clays and silts of the lower unit of the Ringold Formation. Laterally, the unconfined aquifer is bounded by the basalt ridges that surround the basin and by the Yakima and Columbia rivers. The basalt ridges have a low permeability and act as a barrier to lateral flow of ground water (Gephart et al. 1979) where they rise above the water table. The Columbia River acts as a line of discharge for the unconfined aquifer on both sides of the Columbia River. The water table on the west side of the Columbia River is not interrelated with the water table on the east side of the Columbia River.

On the Hanfoid Site, the saturated thickness of the unconfined aquifer is greater than $61 \mathrm{~m}(200 \mathrm{ft})$ in some areas and pinches out along the flanks of the basalt ridges. Depth from the ground surface to the water table ranges from less than $0.3 \mathrm{~m}$ ( $1 \mathrm{ft}$ ) near the Columbia River to more than $106 \mathrm{~m}$ $(348 \mathrm{ft}$ ) near the 200 Areas. In some areas east of the Columbia River, the saturated thickness of the unconfined aquifer is greater than $107 \mathrm{~m}$ (350 ft) and pinches out along the flanks of the basalt ridges. Depth from the ground surface to the water table ranges from $0.3 \mathrm{~m}$ ( $1 \mathrm{ft}$ ) near the Columbia River up to approximately $50 \mathrm{~m}(165 \mathrm{ft})$ in the Esquatzel Coulee. 


\section{DATA COLLECTION}

During June 1991, water levels were measured in 182 wells completed in the unconfined aquifer at the Hanford Site. During July and August 1991, water levels were measured in 66 wells completed in the unconfined aquifer in Grant, Adams, and Franklin Counties north and east of the Columbia River, Additional measurements were taken in 111 wells, also completed in the unconfined aquifar, near U Pond, B Pond, the 100-N Area, 1.100 Area, 3000 Area, and the 30 a Area. Seventeen water levels measured across the Hanford Site during December 1991 were used to determine water-level challges between December 1990 and December 1991. Additional measurements for Decenber 1991 were recorded in the Hanford Ground Mater Data Base.

Most monitoring well. at the Hanford Sice used for water-level measurement are 15 or $20 \mathrm{~cm}(6$ or $8 \mathrm{in}$.$) in diameter and are constructed of stee 1$ casing (McGhan 1989). Several small-diameter [5-clll (2-in.)] piezometers and some larger diameter wills are also used. Wells ccnstructed for Resource Conservation and Recovery ACt (RCRA) ground-wate: monitoring) are 10 or $15 \mathrm{~cm}$ (4 or 6 (n.) in diameter and are constructed of stainless stieel. Monitoring wells used to measure water levels for the unconfined aquifer are completed with well screens or perforated casing generaliy open to the upper 3 to $6 \mathrm{~m}$ (10 to $20 \mathrm{ft}$ ) of the aquifer. This type of completllon allows measurements representative of the water-table elevation. Mast of tho observation wells monitored by the USBR are $4,8,10$, or $15 \mathrm{~cm}(1.5,3,4$, or 6 in.) in diameter and are completed with perforated steel casing (Waiters and Grolier 1960). Well locations for water-level monitoring are shown in Figure 2.

A written procedire developed in accordance with the techniques described in American Society for Testing and Materials (ASTM 1988), U.S. Environmental Protection Agency (EPA 1986), Garber and Koopman (1968), and U.S. Geological Service (USGS 1977) was followed to measure water levels in piezometers and wells across the Hanford Site, including the specific area around the decomissioned U Pond (PNL 1989). Hestinghouse Hanford Company used the procedure described in MHC (1989) to measure watter levels at the Hanford Site, including areas around $B$ Pond, in tha 100.N Area, in the 1100 


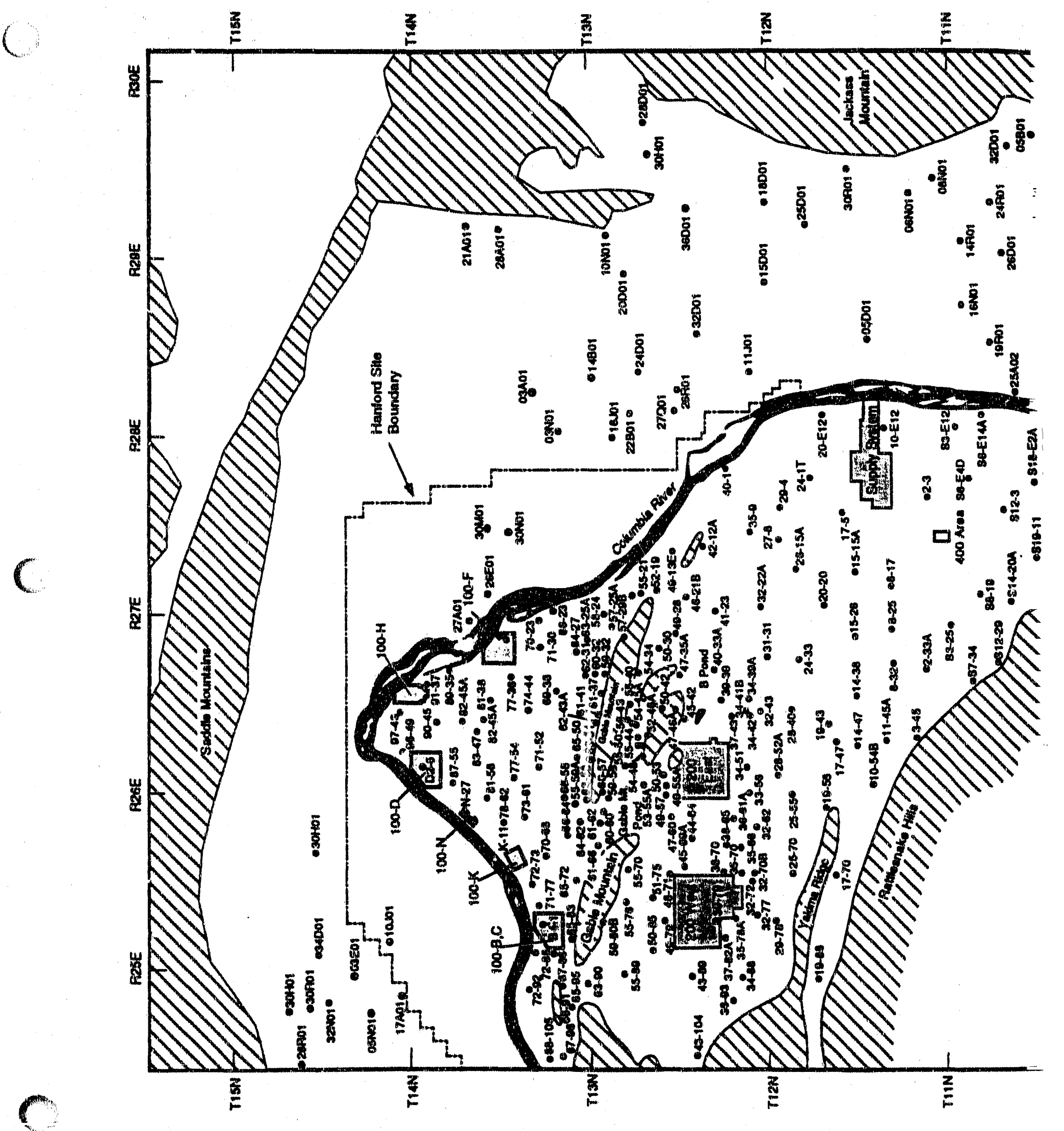




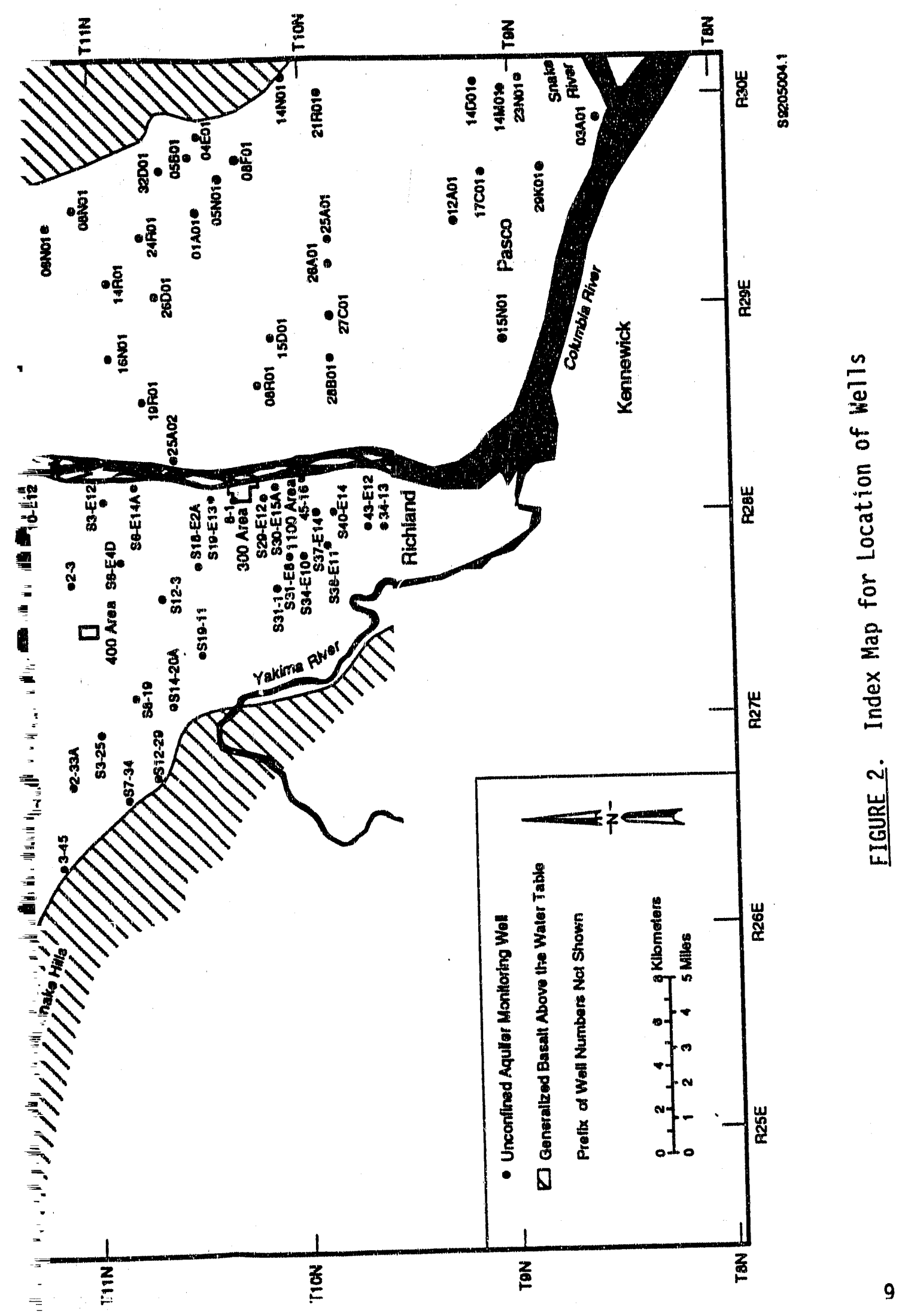


and 3000 Areas, and in the 300 Area. Both PNL and WHC use a calibration well to standardize the steel tapes. However, PNL uses only those standardized steel tapes for measuring water ievels that deviate in length from the calibrated steel tape by less than $0.10 \mathrm{ft}( \pm 0.10 \mathrm{ft})$. Westinghouse Hanford Company applies a correction, based on a proportion of the depth-to-water between the measured well and the calibration well, to the depth-to-water measurement, regardless of the magnitude of deviation between the standardized steel tape and the calibrated tape. The USBR measures water levels with an electric sounding tape or a steel tape. Although no formal written procedure is documented, the USBR follows standard water-level measurement procedures.

In accordance with the water-level measurement procedure described in PNL (1989), a chalked, standardized steel tape was used to measure the depth to the water surface in units of feet from a surveyed measuring point. These measurements were repeated to confirm the initial value. If the second measurement differed by more than $0.02 \mathrm{ft}$ from the first, the water level was remeasured until two measurements within this tolerance were obtained. Measurements weie compared to previous measurements of depth to water to provide a check for gross errors.

Elevation of the water table was determined by subtracting the depth-towater measurement from the elevation of the surveyed measuring point marked on the well casing. The reference for all reported elevations is mean sea level. The elevation of the water-table surface, $S$, can be expressed as

$$
S=E-D
$$

where $S=$ elevation of the water-table surface above mean sea level

$E=$ elevation of surveyed measuring point above mean sea level

$D=$ depth to the water-level surface in the piezometer or well, measured below the surveyed measuring point.

All Hanford Site water-level measurements (June 1991) and all waterlevel measurements from the areas east and north of the Columbia River (JulyAugust 1991) were collected within respective one-month periods. - The greatest short-term water-level changes that occur within these periods were in wells 
for foldout influenced by fluctuations in Columbia River stage. Water-level fluctuations in wells influenced by river-stage fluctuations may introduce errors in representing the water-table surface adjacent to the river. In Plate 1, it should be noted that there is some variability in the location of the contours adjacent to the river.

The difference in time when the Hanford Site water levels were measured (June 1991) versus when the offsite water levels were measured (July-August 1991) merely reflects a difference in the water-level monitoring schedules implemented by the USBR and by PNL and WHC. This does not cause errors by superimposing water-table contours from these two periods because the Columbia River acts as a hydraulic boundary separating two distinct unconfined aquifers whose hydraulic heads are not interrelated. Water-level changes between these two measurement periods (June 1991 and August 1991), on each side of the Columbia River, are negligible compared to the contour interval and scale used for contouring the water-table map, as shown in Plate 1.

sther minor uncertainties in the water-level measurements are caused by effects from diurnal changes (e.g., barometric effects, earth tides), deviations from the vertical in wells, errors in the elevation of the surveyed measuring points, and errors within the measuring tolerances of the field equipment. 


\section{RESULTS}

Water levels measured on the Hanford Site and outlying areas between June and August 1991 are listed in Appendix A. Water levels measured on the Hanford Site during December 1991 are listed in Appendix B. Water level's measured during June 1991 for specific areas within the Hanford Site are listed in Appendix C.

The Hanford Site water-table map, presented in Plate 1, was constructed by hand-contouring the values of water-level elevations for the Hanford Site (June 1991) and outlying areas (July-August 1991). The contours in Plate 1 are in units of meters and the contour interval is $2 \mathrm{~m}$ west and south of the Columbia River (the Hanford Site proper) and $50 \mathrm{~m}$ north and east of the Columbia River.

The locations of the wells are indexed in Figure 2. Wells north and east of the Columbia River are numbered by the USGS we11-numbering system, prefixed by township and range. Wells on the Hanford Site, west of the Columbia River, are named with their Hanford coordinates. Top of basalt maps from Myers et al. (1979) were used to estimate the generalized outcrop of basalt above the water table.

In the area between the Saddle Mountains and the Columbia River extending southeast to Columbia Flat, the water-table contours are inferred from water-level data collected by the USGS in 1989 (Drost et al. 1989). Unpublished water-table maps by the USGS, using the 1989 data, indicate that the contours are controlled by the basalt surface and the topography. Comparison between 1989 and 1991 water-level data indicates that the water-table elevation in this area has not changed significantly between 1989 and 1991. 


\section{HANFORD SITE WATER-TABLE FEATURES}

The following are important features of the Hanford Site water-table map:

- Water-table elevations generally decrease from west to east across the Hanford Site south of Gable Mountain and Gable Butte.

- Water-table elevations decrease northward through the gap between Umtanum Ridge and Gable Butte and the gap between Gable Butte and Gable Mountain.

- The hydraulic gradient of the water table decreases abruptly between the 200-West and 200-East Areas.

- Ground-water mounds are present beneath B Pond, the location of decommissioned U Pond, and the 1100 Area.

- The water level in the Yakima River is of higher elevation than that of the water table in the adjacent region of the Hanford Site.

Elevated water levels in the western region of the Hanford Site may be attributable to ground-water recharge in Cold Creek and Dry Creek Valleys and on the adjacent ridges (i.e., Yakima, Umtanum, and Rattlesnake ridges). The source of recharge is most likely infiltration of rain and snow at the higher elevations and offsite irrigation of agricultural land at the lower elevations.

Water-table elevation generally decreases toward the Columbia River at the eastern edge of the Hanford Site and north of the Gable Mountain-Gable Butte anticline, implying discharge of unconfined ground water to the Columbia River along the Hanford reach. The Hanford reach is the free-flowing stretch of the Columbia River between Priest Rapids Dam and the city of Richland.

The abrupt change in the hydraulic gradient of the water table between the 200-West and 200-East Areas is attributed to an increase in the hydraulic conductivity of the sediments from west to east (Graham et al. 1981).

Ground-water mounds beneath $B$ Pond and the decommissioned $U$ Pond have been caused by process cooling water and other liquid wastes recharging the ground water at those locations. The ground-water mound beneath the 
1100 Area, which is discussed later, has been caused by recharge from the city of Richland's recharge infiltration basins.

The elevation of the water table in the region between the Yakima River, near Horn Rapids Dam, and the Columbia River is lower than the Yakima River stage, which is approximately $122 \mathrm{~m}$ (400 ft) above mean sea level. This implies that unconfined ground water is being recharged by the Yakima River. Water levels measured in this region also indicate that ground water recharged by the Yakima River flows to the east beneath the southern portion of the Hanford Site and discharges to the Columbia River. 


\section{CHANGES IN THE HANFORD SITE WATER TABLE DURING 1991}

The most prominent changes to the water table at Hanford between December 1990 and December 1991 occurred beneath the 200 Areas, which inciude the decommissioned $U$ Pond in the 200-West Area; beneath B Pond, located in the 600 Area east of the 200-East Area; beneath and adjacent to the 1100 and 3000 Areas; beneath the upper Cold Creek Valley west of the 200 Areas; and along the Hanford reach of the Columbia River, which includes the 100-N and 300 Areas, where wastewater discharge facilities have influenced the water table. The latest summary of wastewater discharges to disposal facilities in the 200 and 600 Areas is presented by Brown et al. (1990).

\section{AREAS}

The elevation of the water table beneath the 200 Areas declined between December 1990 and December 1991. The water table declined approximately $0.21 \mathrm{~m}(0.7 \mathrm{ft})$ beneath most of the 200 Areas. These declines are primarily attributed to 1) an overall decrease in wastewater discharged to various cribs, trenches, and ponds in the 200 Areas and 2) continued dissipation of the ground-water mound beneath U Pond since it was decommissioned in 1984 . The decrease in wastewater discharge corresponds to the shutdown of production facilities in the 200 Areas. Ground water in the 200 Areas is also influenced by a ground-water mound beneath $B$ Pond. Because of its proximity to and influence on 200-Area ground water, the ground-water mound beneath $B$ Pond is discussed here.

\section{6-B-3 Pond}

A map of the water table influenced by 216-B-3 Pond ( $B$ Pond), presented in Figure 3 , indicates that ground water flows radially from beneath $B$ Pond. The elevation of the water table declined between December 1990 and December 1991. The water-level data shows that the largest decline was $0.30 \mathrm{~m}$ $(1.0 \mathrm{ft})$, observed in well 699-41-40. Hydrographs of wells 699-39-39, located southeast of B Pond; 699-42-40B, located at the center of the ground-water 


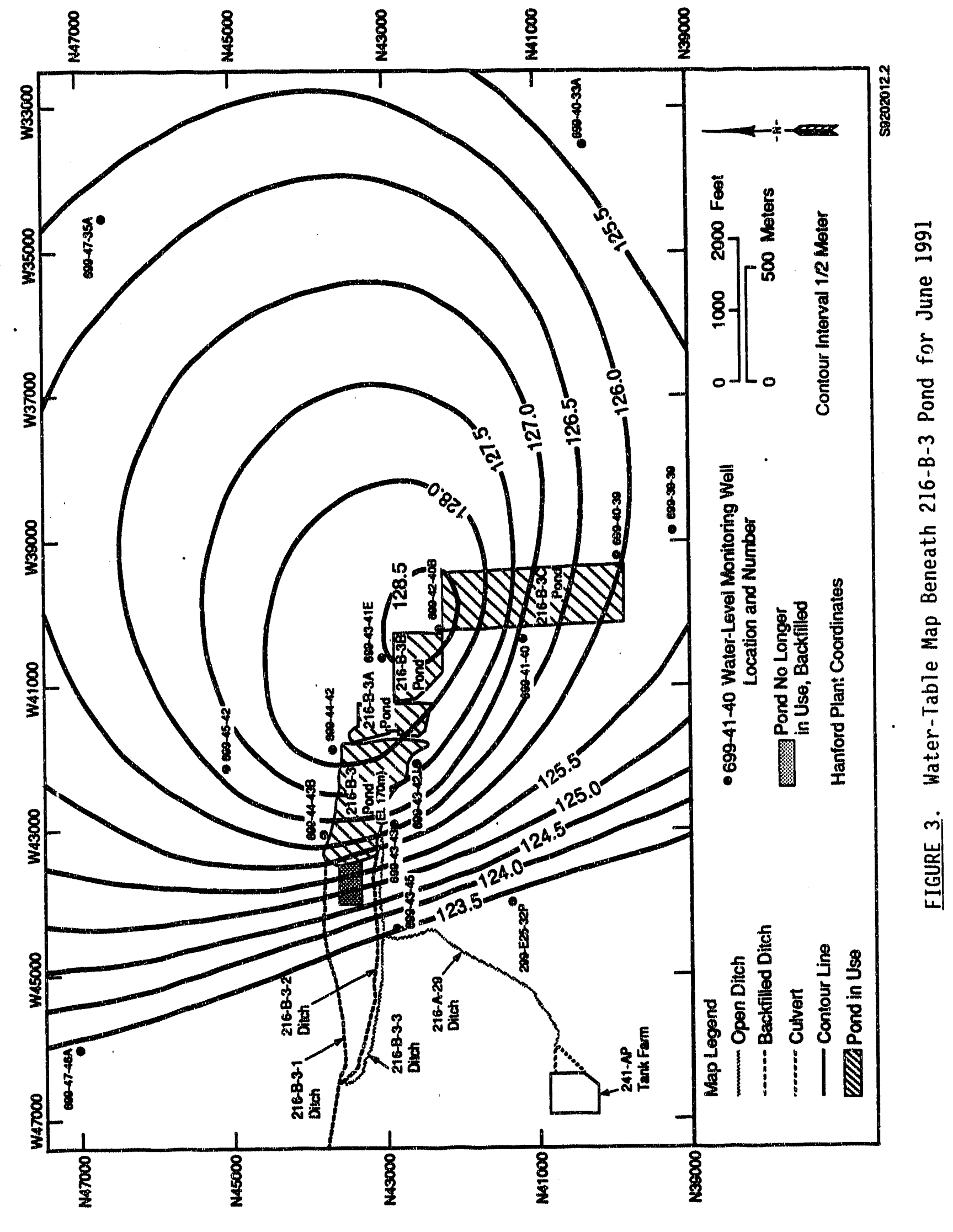


mound; 699-40-39 and 699-41-40, located between wells 699-39-39 and 699-42-40B around the perimeter of 216-B-3C Pond, are presented in Figure 4.

Newcomer et a1. (1991) reported that the water level in we11 699-39-39 has been changing significantly and independently of nearby, wells since 1987 . Such changes were not observed during calendar year 1991. As shown in Figure 4, the water level fluctuations in this well were consistent with changes in the nearby wel1s 699-40-39 and 699-40-41.

A water-table map of B Pond for June 1990 is presented in Newcomer et al. (1991). Water-table maps of the Separations Areas for December 1990 and June 1991, which include the B Pond area, are presented in Kasza et al. (1991a) and Kasza et al. (1991b), respectively.

\section{Decommissioned U Pond}

A map of the water table beneath the decommissioned $U$ Pond is presented in Figure 5. This map indicates that ground water flows radially, mostly to the north and east from an area near the 216-U-14 Ditch, located eastnortheast of the decommissioned $U$ Pond. This ditch continues to receive waste water (Brown et al. 1990). The water-table map for the Hanford Site and outlying areas in Plate 1 indicates that the ground-water mound in this area has influenced regional ground-water flow.

The elevation of the ground-water mound beneath the 200-West Area has continued to decline since $U$ Pond was decommissioned in 1984. The maximum elevation of the ground-water mound, which occurred in 1984, was approximately $148 \mathrm{~m}(485 \mathrm{ft})$ above mean sea leve1. The elevation of the ground-water mound beneath the decommissioned $U$ Pond, as reflected in the water level in well 299-W18-15, decreased as much as $5.12 \mathrm{~m}$ (16.8 ft) between June 1984 (RHO 1984) and June 1991. Between December 1990 and December 1991, the elevation of the ground-water mound decreased as much as $0.18 \mathrm{~m}(0.6 \mathrm{ft})$, as reflected in the water level in well 299-W19-01. This decline in the elevation of the groundwater mound beneath the deactivated $U$ Pond has been observed in wells throughout the 200-West Area. 


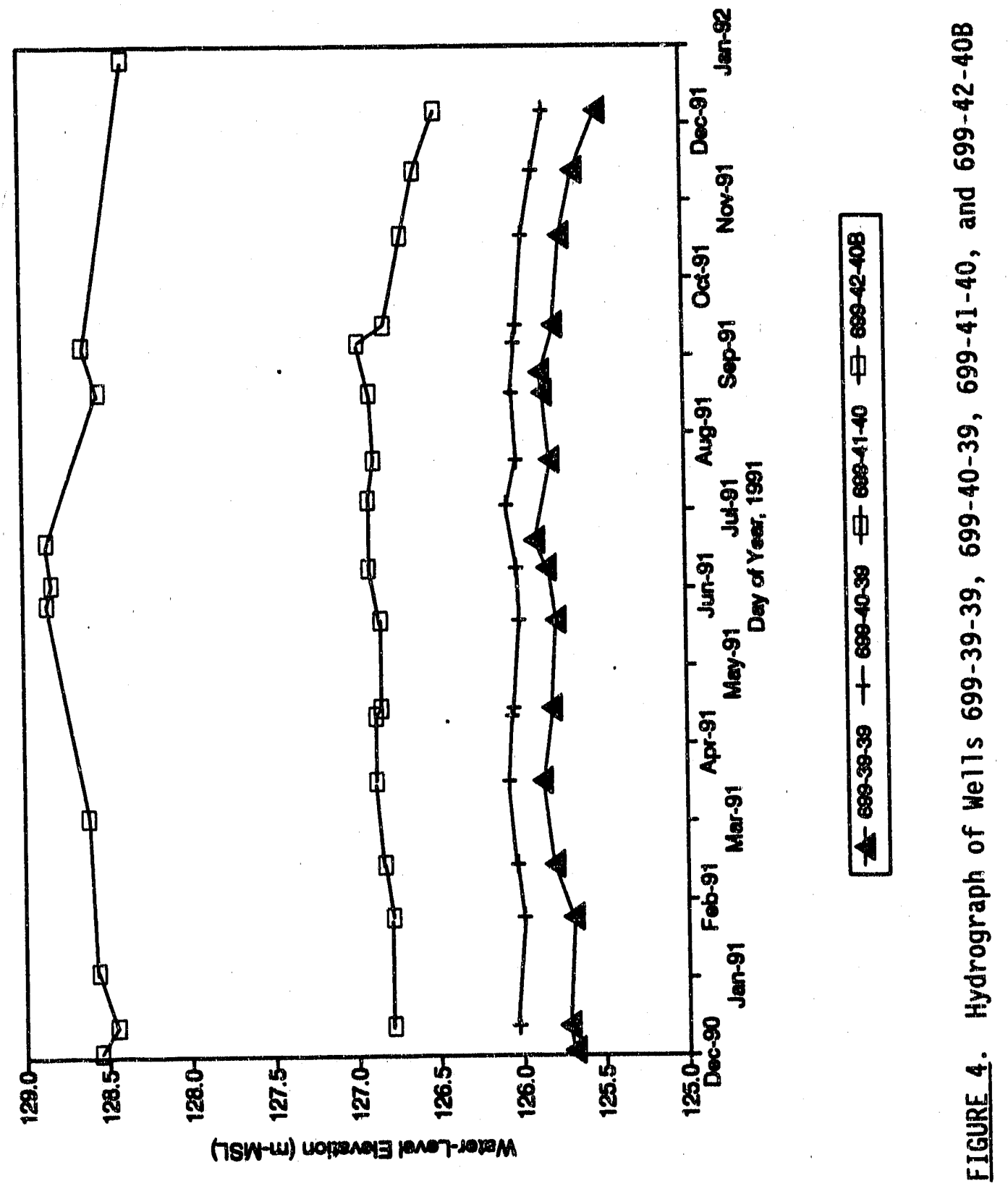




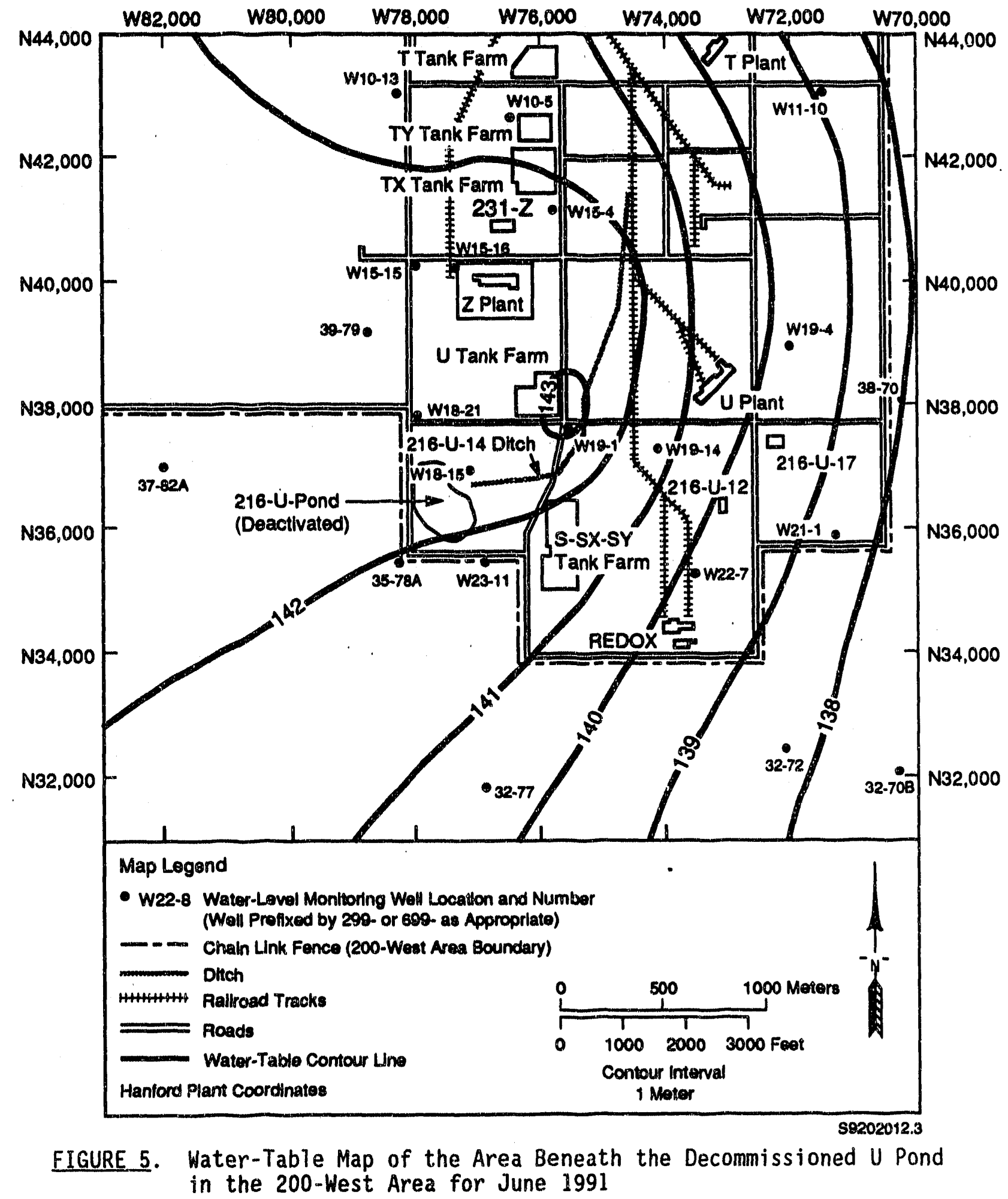


Hydrographs of we17s 299-W10-13, 299-W18-21, and 299-W19-01, for which water levels declined between December 1990 and December 1991, are presented in Figure 6. The locations of these wells are shown in Figure 5. A watertable map of the U Pond area for June 1990 is presented in Newcomer et al. (1991). Water-table maps of the Separations Areas for December 1990 and June 1991, which include the deactivated U Pond area, are presented in Kasza et al. (1991a) and Kasza et al. (1991b), respectively.

\section{AND 3000 AREAS}

Ground water beneath the 1100 and 3000 Areas generally flows from west to east between the Yakima and Columbia rivers. The sources of recharge are the ground-water recharge basins associated with the North Richland well field and recharge from irrigation in the 3000 Area and west and southwest of the 1100 Area. The source of pumping are the North Richland well field and wells used for irrigation.

A water-table map of the 1100 and 3000 Areas, illustrated in Figure 7, indicates that a ground-water mound lies beneath the system of recharge basins. The ground-water mound developed as a result of recharge exceeding pumping: At the North Richland well field, water is pumped from the intake structure at the Columbia River and piped to a system of basins (ICF 1987), which recharges the unconfined aquifer. Water is then pumped from the aquifer via the well field for the city's water suppiy system. This system is primarily used as a backup system between January and March each year when filtration $p l a n t$ is shut down for maintenance and during the summer months to supplement the city's water supply. A hydrograph of well 699-S40-E14, presented in Figure 8 , shows the water-level response to pumping and recharge during 1991. The water level reached a low of about $106.50 \mathrm{~m}(349.4 \mathrm{ft})$ in March 1991 followed by a rise in the water level to over $109 \mathrm{~m}(357 \mathrm{ft})$. Well 699-S40-E14 is located on the western edge of the recharge basins (see Figure 7).

Ground-water levels in the 1100 and 3000 Areas are influenced by irrigation practices. The sources of irrigation water are the Columbia River and a 


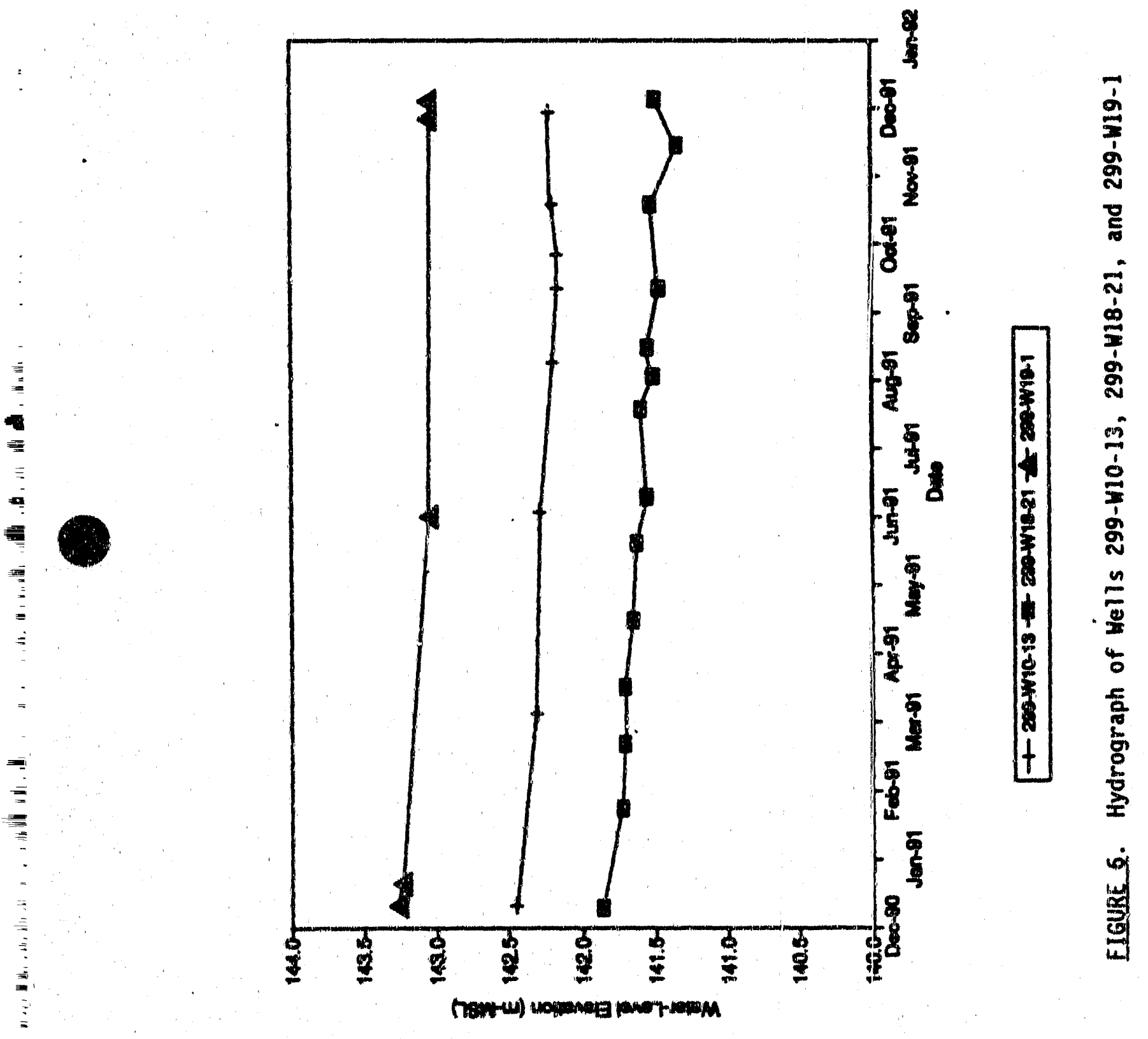




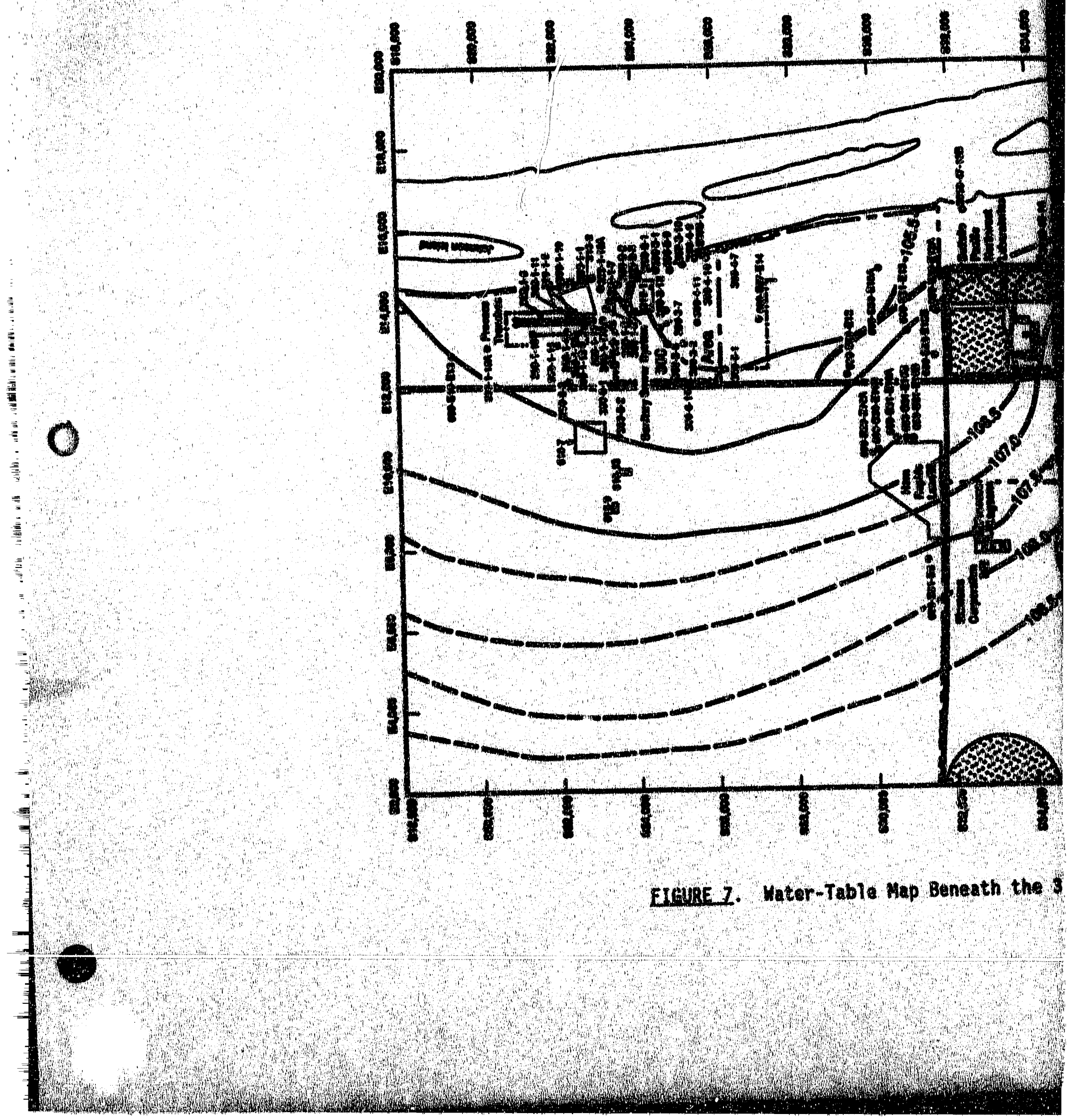




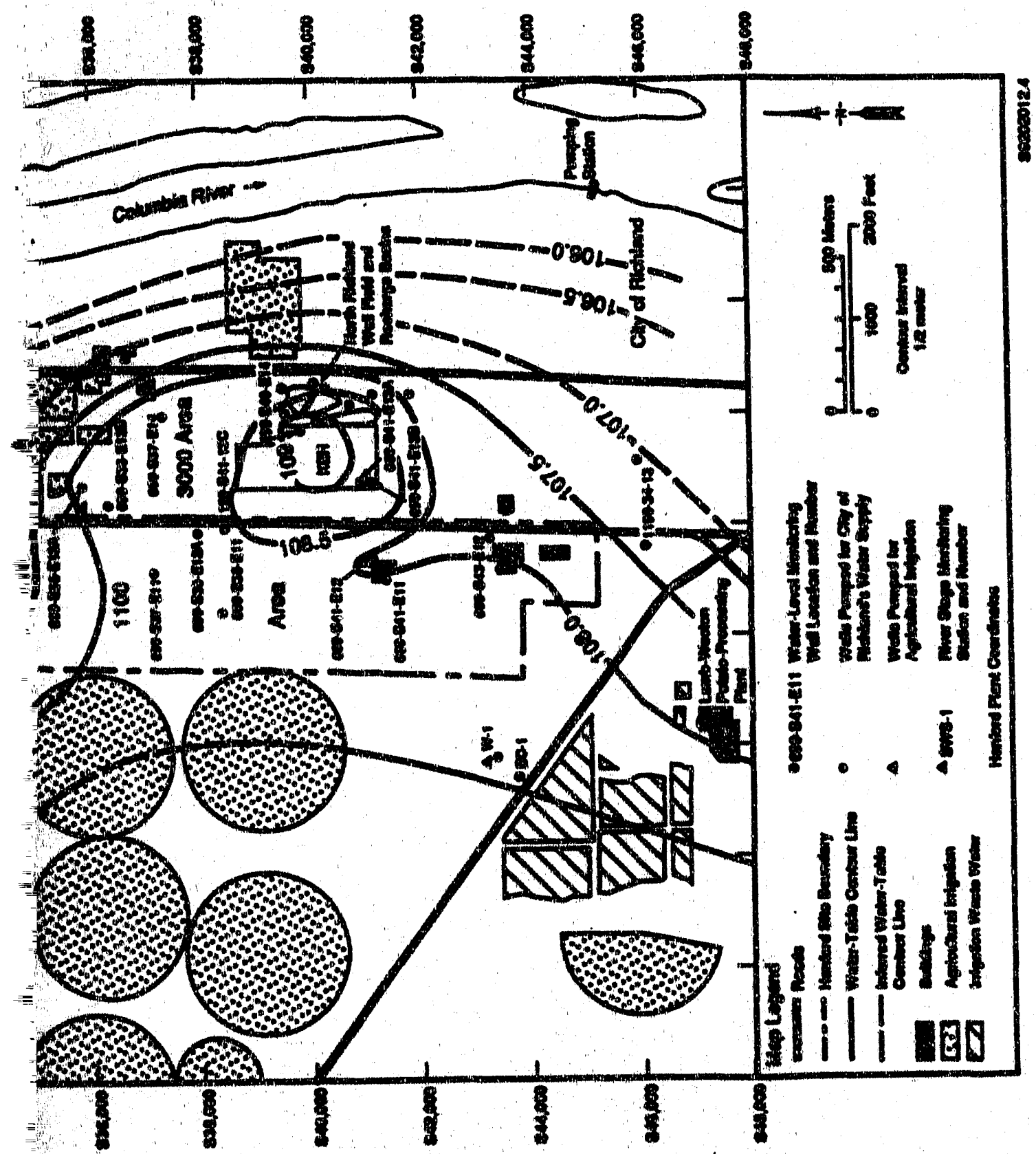

6.1100, and 3000 Areas for June 1991 


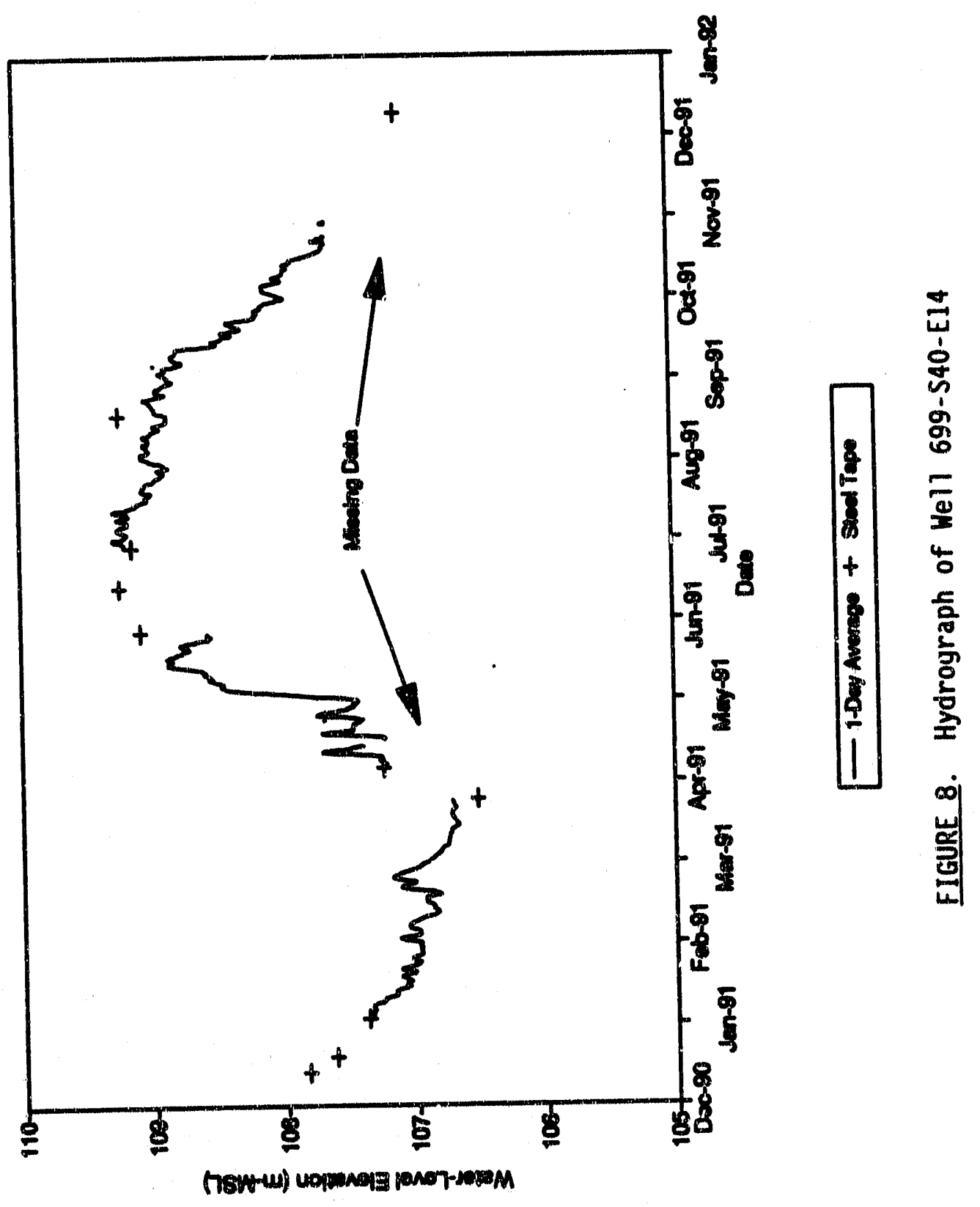


shallow pumping well near two wells informally called EC-1 and W-1 (see Figure 7). Water-level data indicate that water levels in the vicinity of the North Richland well field declined as much as $0.94 \mathrm{~m}(3.1 \mathrm{ft})$ between December 1990 and December 1991. However, water levels around the perimeter of the heavily irrigated fields west and southwest of the 1100 Area, between Horn Rapids Landfill and Lamb-Weston Potato-Processing Plant, actually rose as much as $0.49 \mathrm{~m}$ (1.6 ft) between December 1990 and December 1991. The water level in well 699-\$31-1, located approximately 2 miles west of the Horn Rapids Landfill along the northern perimeter of the irrigation fields (see Figure 2), rose $0.91 \mathrm{~m}(3.0 \mathrm{ft}$ ) between December 1990 and December 1991 .

Wells EC-1 and 1199-34-13 are examples of wells whose water levels are responding to irrigation west of the 1100 Area. Hydrographs of these wells, located near the south end of the 1100 Area, are shown in Figure 9. The water level in well 1199-34-13 is interpreted to be responding primarily to recharge from irrigation west and southwest of the 1100 Area. Water levels observed in this well are also influenced by the North Richland well field. The hydrograph in Figure 9 shows that the water-level elevation in well 1199-34-13 fluctuated cyclically between a low of approximately $107.14 \mathrm{~m}(351.5 \mathrm{ft})$ in April 1991, the beginning of the growing season, to a high of approximately $107.87 \mathrm{~m}(353.9 \mathrm{ft})$ in October 1991, the end of the growing season. The corresponding hydrograph of well EC-1 in Figure 9 shows a water-level cyclic response inverse to that of well 1199-34-13. The water level in well EC-1 is responding mostly to pumping from nearby irrigation wells. Comparison of the 1990 and 1991 water-level data in Figure 9 shows that a net water-level rise, ranging from 0.21 to $0.30 \mathrm{~m}(0.7 \mathrm{ft}$ to $1.0 \mathrm{ft})$, is superimposed on the cyclic water-level fluctuations. The largest increase in water-level elevation between December 1990 and December 1991 was approximately $0.9 \mathrm{~m}(3 \mathrm{ft})$, observed in well 699-S31-1 (see Figure 2 for location).

\section{UPPER COLD CREEK VALLEY}

Zimmerman et a1. (1986) postulated that the water table in the western part of the Hanford Site responded to irrigation practices in the upper Cold Creek Valley. A hydrograph of well 699-43-104, located downvalley from the 


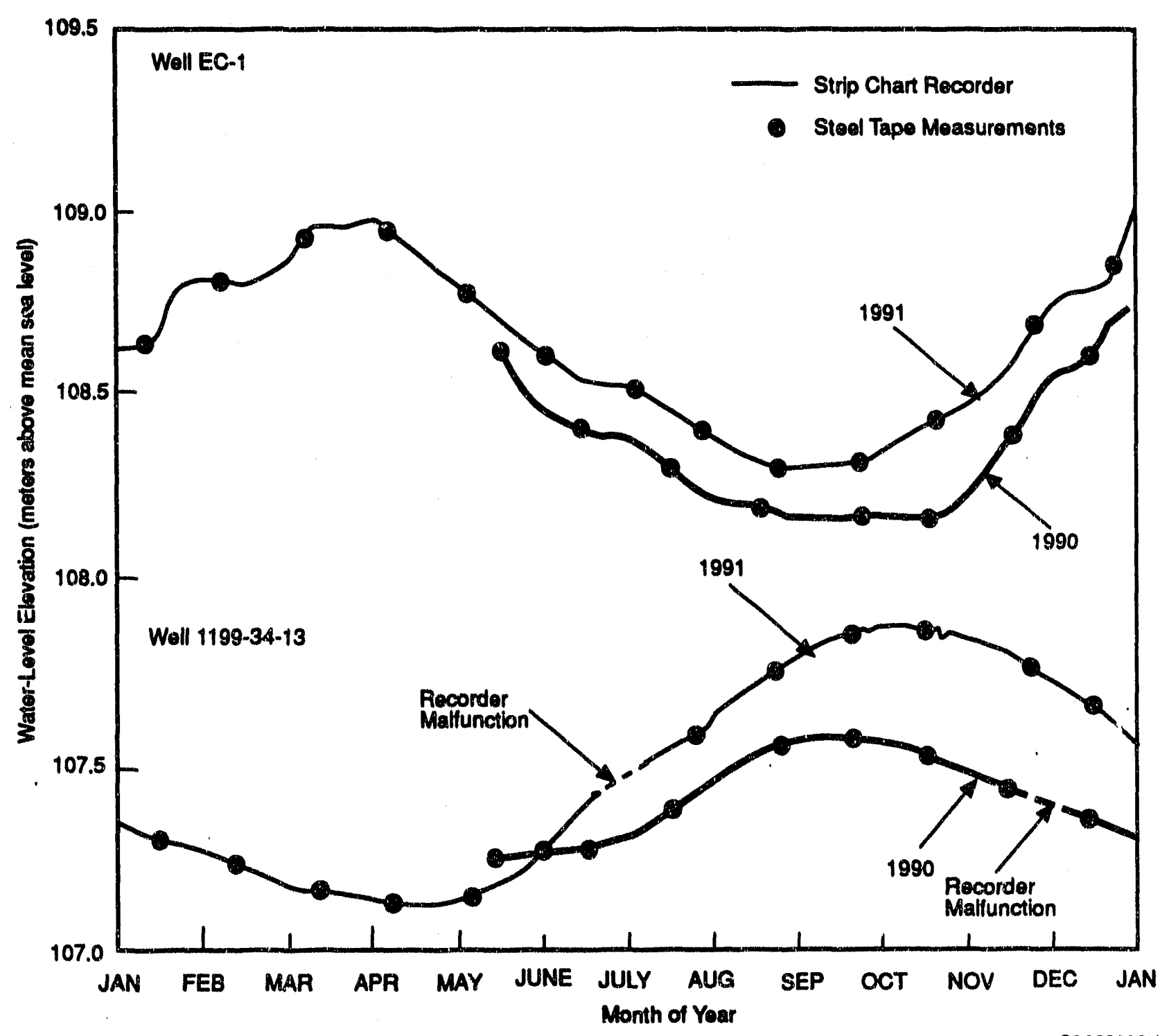

EIGURE 9. Hydrograph of Wells EC-1 and 1199-34-13 
irrigation fields in upper Cold Creek Valley (see Figure 2), is shown in Figure 10. The hydrograph indicates that the water table declined steadily during 1991. The water level declined approximately $0.49 \mathrm{~m}(1.6 \mathrm{ft})$ between March 1991, when monitoring began, and December 1991. Water leve1s in this well have declined since about 1988. It is hypothesized that the declining water level in this well is responding to less irrigation water recharging the unconfined aquifer due to changes in irrigation practices by St. Michelle Vineyards. Between 1982 and 1983, St. Michelle Vineyards converted their irrigation system from a sprinkler system to drip irrigation, which reduced consumptive use by $40 \%$ to $50 \%$ (Newcomer 1990). The observed water-leve] decline may also be responding to dissipation of the ground-water mound beneath the 200-West Area.

\section{HANFORD REACH}

Water-level changes also occurred in wells near the Columbia River. Water levels have been observed to fluctuate several feet in response to the rise and fall of the river stage. These changes are the result of pressure waves transmitted from the river to the unconfined aquifer, but also include bank storage effects. Hydrographs showing the influence of the river stage on the unconfined aquifer at various locations along the Columbia River are presented in Jensen (1987), Liikala et al. (1988), Schalla et al. (1988), and Fruland and Lundgren (1989). The Columbia River stage changes in response to releases at the Priest Rapids Dam upstream from the Hanford reach and to seasonal influences. Ground water in the 100-N and 300 Areas are heavily influenced by river stage fluctuations; therefore water-level changes in these areas will be discussed below.

\section{$100-N$ Area}

The Hanford Site water-table map indicates that ground water passing beneath the 100-N Area flows north through the gap between Gable Butte and Gable Mountain and discharges to the Columbia River. Ground-water elevations in the 100-N Area are primarily influenced by changes in Columbia River stage and recharge from wastewater disposal facilities in the 100-N Area. 


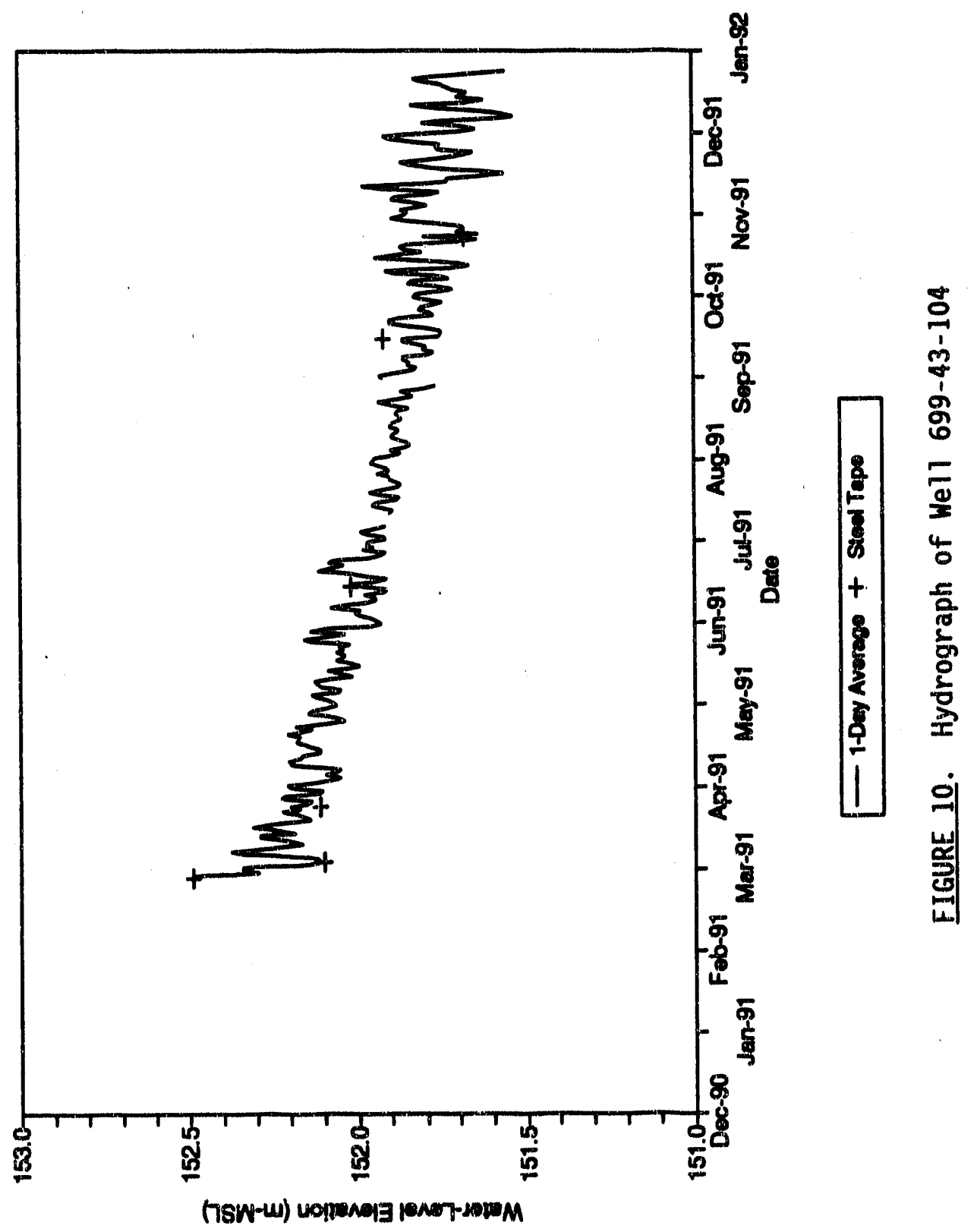


A water-table map of the 100-N Area for June 1991 is shown in Figure 11. Ground-water mounding beneath the 100-N Area has largely dissipated since the $N$ Reactor went on standby, and water levels continue to decline. Hydrographs of wells 199-N-27 and 199-N-60, located in the 100-N Area, and 699-81-58, located southeast of the 100-N Area, 'are shown in Figure 12. The locations of wells 199-N-27 and 199-N-60 are shown in Figure 11 and wel1 699-81-58 in Figure 2. The hydrograph of well 199-N-27, located near the 1325-N liquid waste disposal facility, indicates that the water level declined approximately $0.27 \mathrm{~m}(0.9 \mathrm{ft})$ between December 1990 and December 1991. The hydrograph of well 199-N-60, located near the 1324-N/NA liquid waste disposal facility, indicates that the water level declined approximately $0.17 \mathrm{~m}(0.6 \mathrm{ft})$ between December 1990 and December 1991. The hydrograph of well 699-81-58, 1ocated southwest of the 100- $\mathrm{N}$ Area, indicates that the water level declined $0.34 \mathrm{~m}$ $(1.1 \mathrm{ft})$ between December 1990 and December 1991. These declines are primarily the consequence of reduced wastewater discharge to the $1325-\mathrm{N}$ and 1324-N/NA facilities. As expected, water levels in wells near the Columbia River generally increased between December 1990 and June 1991 and declined between June 1991 and December 1991, primarily as the result of the rise and fall of the river stage.

A water-table map of the $100-N$ Area for June 1990 is presented in Newcomer et a1. (1991). Water-table maps of the 100 Areas for December 1990 and June 1991, which include the 100-N Area, are presented in Kasza et al. (1991a) and Kasza et al. (1991b), respectively.

\section{Area}

A water-table map of the 300 Area for June 1991 is shown in Figure 7. The water-table contours indicate that ground water flows from the northwest, west, and southwest and discharges to the Columbia River in the vicinity of the 300 Area. The primary influence on the ground-water elevation in the 300 Area is changes in Columbia River stage. The water table beneath the 300 Area is also influenced by recharge from the process trenches. These trenches have received large volumes of process water (Schalla et al. 1988). The configuration of the water table at any given time is dependent on these influences. 


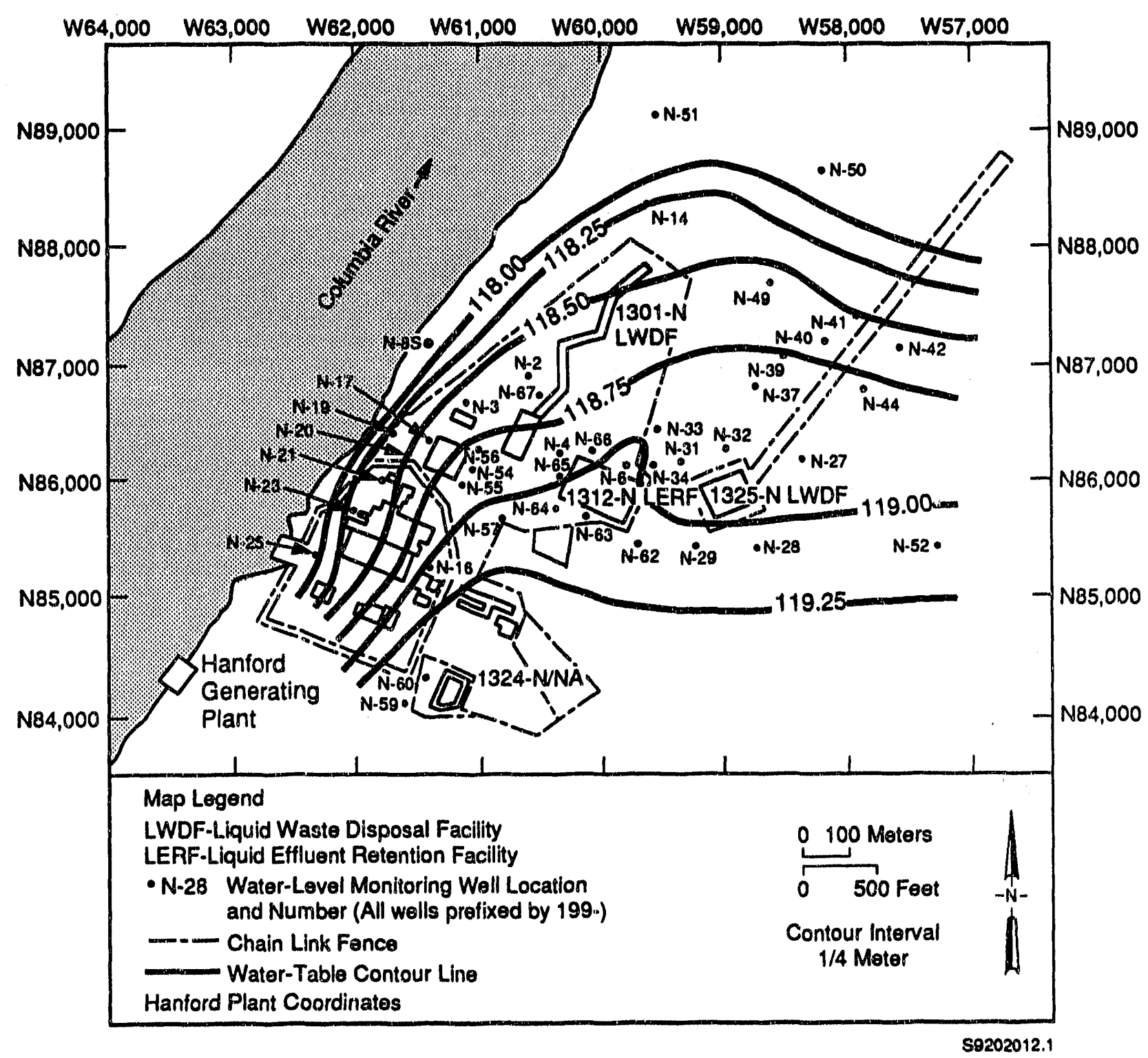

FIGURE 11. Water-Table Map Beneath the 100-N Area for June 1991

The water table declined over $0.30 \mathrm{~m}(1 \mathrm{ft})$ in most of the 300 Area between December 1990 and December 1991. This decline is primarily the result of the decline in Columbia River stage. A hydrograph for well 399-8-1, shown in Figure 13, illustrates that the primary water-level response to the river stage occurred during spring of 1991. A water-table map of the 300 Area for June 1990 is presented in Newcomer and McDonald (1990). 


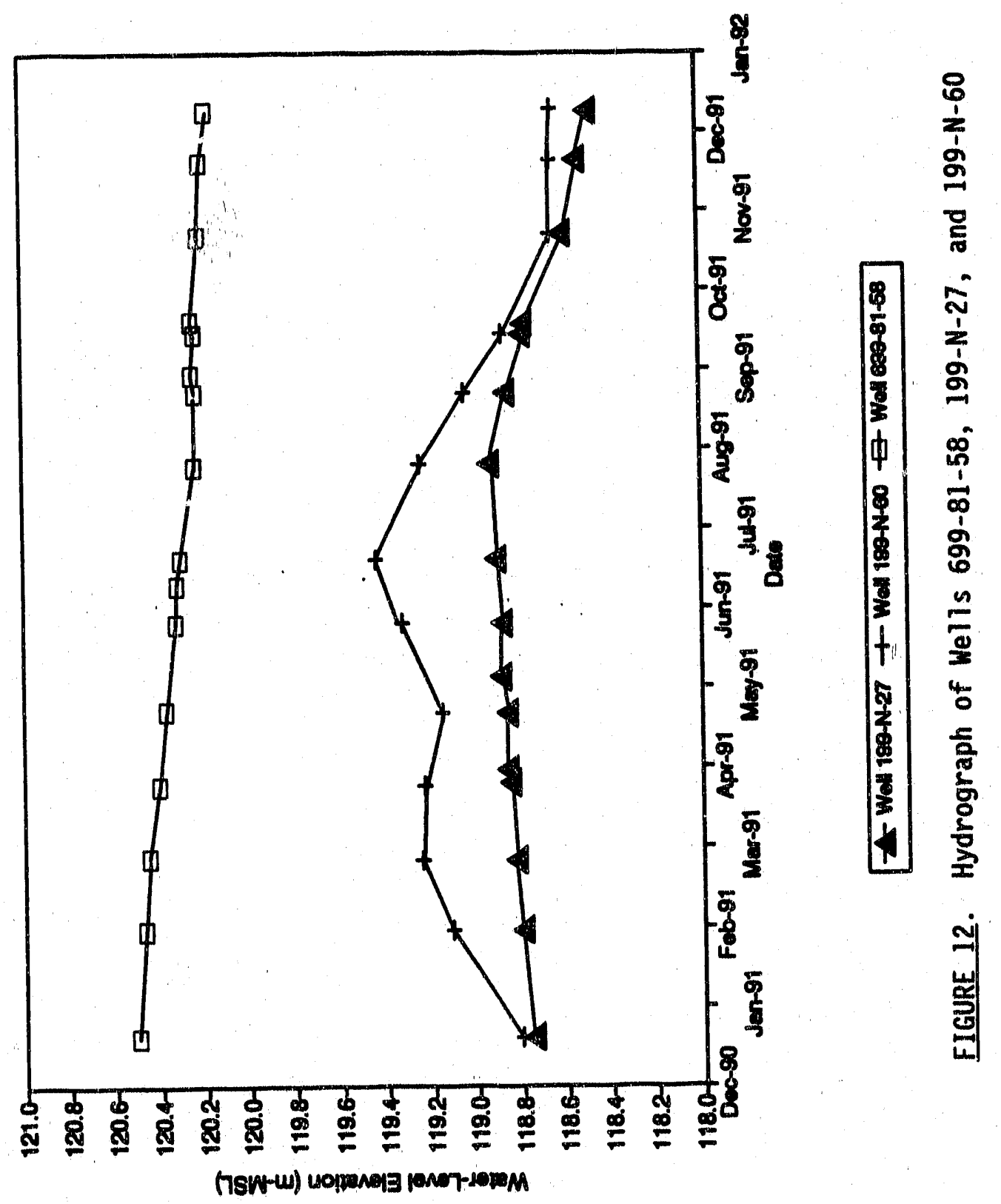




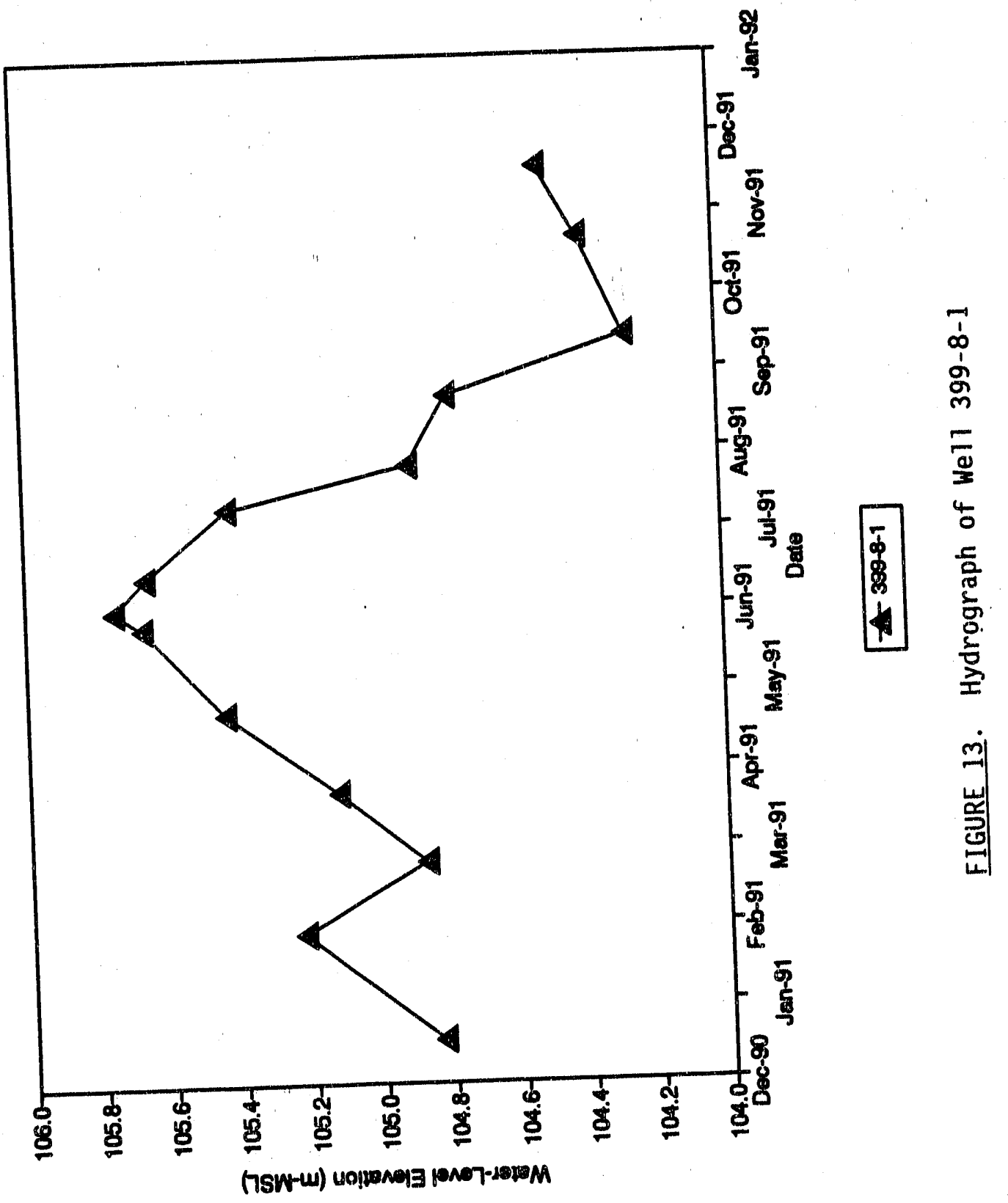




\section{WATER-TABLE FEATURES EAST AND NORTH OF THE COLUMBIA RIVER}

The dominant pattern of unconfined ground-water flow in the outlying areas east and north of the Columbia River is downward movement from the anticlinal axes of the basalt ridges toward the Columbia River lying within a syncline. Bauer et a1. (1985) reported that lateral water-table gradients appear to be approximately equal to or slightly less than the structural gradients on the flanks of the anticlines or where the basalt is steeply dipping. Plate 1 depicts steep water-table gradients on the flanks of the Saddle Mountains anticline. Bauer et al. (1985) indicated that water-table conditions are known to exist in the uppermost basalt flows, but did not specify the locations where these conditions exist.

The water-table configuration is heavily influenced by recharge from irrigation practices in the region between the Columbia River and the basalt anticlinal ridges. The effects of human-induced recharge on the water-table configuration are shown by the downgradient contour flexures and ground-water mounding in Plate 1 .

The outlying areas east and north of the Columbia River are irrigated by the South Columbia Basin Irrigation District, which is part of the Columbia Basin Irrigation Project (Brown 1979). The South Columbia Basin Irrigation District consists of two principal areas. The majority of one area is located east of the Columbia River and the Hanford Site boundary, extending from the north to south between the lower flanks of the Saddle Mountains and the Esquatzel Diversion channel (see Plate 1). This area extends east near Eltopia. The other principal area of irrigation is the northern part of the basin on Wahluke Slope between the Columbia River and the Saddle Mountain anticline. In these district areas, water available for recharging the unconfined aquifer includes leakage from canals and wasteways, surface runoff from irrigated 1 and, discharge or spillover of excess irrigation water, and seepage from the irrigated land itself (Brown 1979). Pumping from wells tapping the unconfined aquifer is mostly used for domestic, stock, and even irrigation purposes, but yield is commonly very low. (Bauer et a1. 1985). For this 
reason, pumping from the unconfined aquifer in the South Columbia Basin Irrigation District has little influence on water levels.

The most dynamic area of ground-water movement in the South Columbia Basin. Irrigation District is in Ringold Cou? ee, where Pasco gravels reside in the coulee floor. Water-level data indicates that the hydraulic gradient is steep along the edge of the coulee, where the topography changes abruptiy. Water in the coulee flows from the area north of Ringold Coulee, between Othello and Eagle Lakes and Scooteney Reservoir. Elsewhere in the irrigation district, the unconfined aquifer lies in the less permeable Ringold Formation.

The water-table map in Plate 1 shows a steep hydraulic gradient along the edge of Columbia River where the steep White Bluffs overlook the river. The abrupt topographic elevation change between the Columbia River drainage and the top of the bluffs resulted in a steep hydraulic gradient when the water level rose in the irrigated areas, as described earlier. The steep hydraulic gradient is illustrated graphically by a cross section in Figure 14 . Figure 14 shows a cross section of the water table and 1 and surface between well 695-43-104 in Cold Creek Valley and well 12/30 30ROl east of Owens Flat. Figure 14 shows that the gradient of the water table is steep between the Columbia River and Owens Flat, but gentle between the Columbia River and Cold Creek Valley.

The rising of the water table east of the Columbia River has resulted in a series of springs issuing from White Bluffs. Brown (1979) reported that runoff from spring discharge at the mouth of Ringold Coulee is over $10,000 \mathrm{gpm}$.

Water-table contours along the Wahluke Slope north of the Columbia River are inferred because of poor data control. However, other sources of information were used to infer the contours. Across the Columbia River from the $100-N$ and 100-K Areas, the elevation of ponds and seeps in the Saddle Mountain Natural Wildlife Refuge, used in conjunction with topographic elevations, indicates that the 150-m contour swings south and east of the ponds (see Plate 1). Along the northeast border of the Hanford Site, contour flexures are inferred from topographic elevations. The shape of the flexures and the 


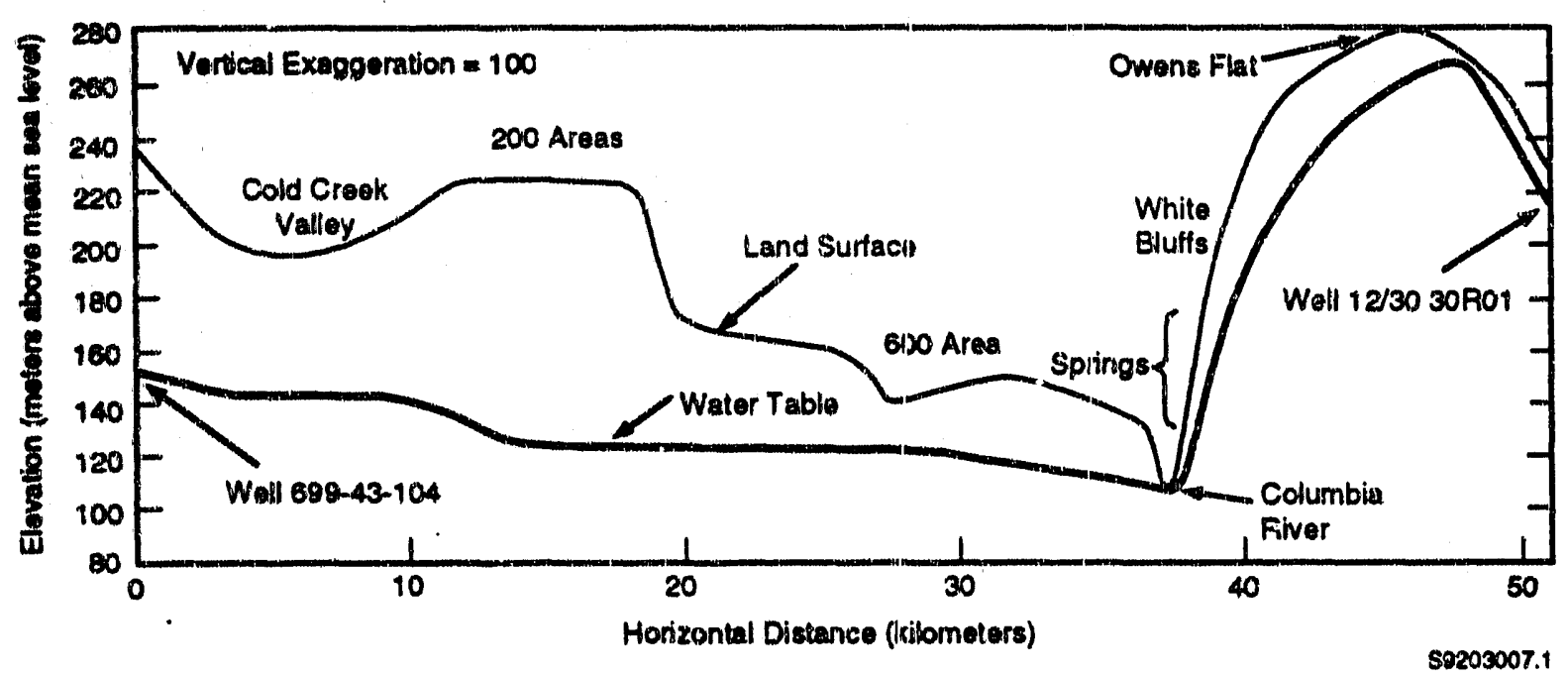

EIGURE 14. Cross Section of the Land Surface and Water Table Between Well 699-43-104 and Well 12/30 30ROI

ground-water mound near Columbia Flat are consistent with those in an unpublished USGS water-table map contoured from water-level data in Drost et al. (1989).

Irrigation on the Wahluke Slope and this area east of the Columbia River has developed extensive perched water bodies (Brown 1979). The extent of perched conditions is not well defined because few wells tap the perched water body. Perched water is also a source for spring discharge along the White Biuffs.

South of the irrigation district between the Esquatzel Diversion channel and the Columbia River near Pasco lies the Pasca Greenbelt Area. In spite of extensive ground-water withdrawal from wells for irrigation, the water table in the Pasco Greenbelt Area has risen in the past in response to drainage from the South Columbia Irrigation District (Brown 1979). The water-table contours in Plate 1 indicates that ground water flows south from the district to the Pasco Greenbelt Area.

Figure 15 shows that the hydraulic gradient becomes less steep as ground water enters the Pasco Greenbelt Area before discharging to the Columbia and Snake Rivers. The highly permeable Pasco gravals are the most prominent of 


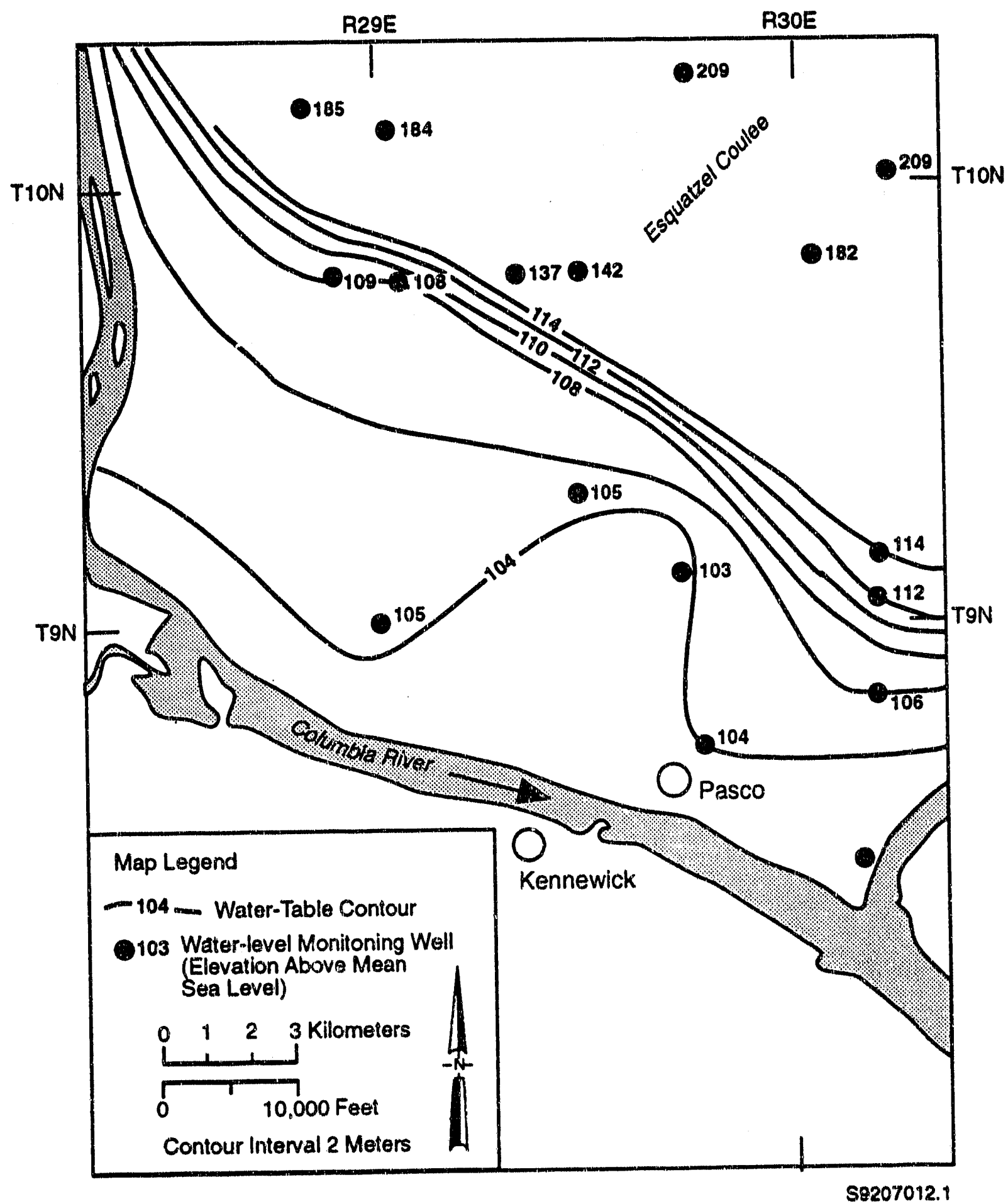

FIGURE 15. Water-Table Map of the Pasco Greenbelt Area 
the unconfined aquifer in the Pasco Greenbelt Area and are the principal reason for the lower water-table gradient (Brown 1979). Esquatzel Coulee, like Ringold Coulee, is an area of dynamic ground-water movement, as shown by the water-table contours in Plate 1. 
The elevation of the water table declined over most of the Hanford Site during 1991, particularly in the vicinity of production facilities in the 200 Areas. The water table responded to disequilibrium conditions caused by decreasing discharge to wastewater facilities. With the shutdown of Hanford production facilities, the water table is expected to continue to decline until new equilibrium conditions are established. The water table also declined beneath the western part of the Hanford Site in Cold Creek Valley and beneath the 100-N Area. Recent irrigation development just south of the Hanford Site boundary between the Yakima River and the 1100 Area has influenced water levels observed in the 1100 Area and its vicinity. Changes in the Hanford Site water table during 1991 are summarized as follows:

- The elevation of the ground-water mound beneath B Pond, which continues to receive wastewater, declined as much as $0.30 \mathrm{~m}(1.06 \mathrm{ft})$ between December 1990 and December 1991.

- The elevation of the water table beneath the 200 Areas, including the water table beneath the decommissioned $U$ Pond, decreased as much as $0.21 \mathrm{~m}(0.7 \mathrm{ft})$ between December 1990 and December 1991, primarily in response to decreasing wastewater discharge to various ponds, cribs, and trenches in the 200 Areas and continued dissipation of the ground-water mound beneath much of the 200-West Area.

- The elevation of the water table in the 1100 and 3000 Areas fluctuated primarily in response to pumping and recharge at the north Richland well field and associated ground-water recharge basins during 1991 and to recharge from irrigation practices west of the 1100 Area.

- The elevation of the water table beneath the western part of the Hanford Site in the Cold Creek Valley decreased approximately $0.549 \mathrm{~m}$ (1.6 ft) between March 1991 and December 1991, primarily due to changes in irrigation practices in the upper Cold Creek Valley, but possibly also in response to wastewater disposal practices in the 200 Areas.

- Significant changes in the elevation of the water table occurred near the Columbia River during 1991. These were caused primarily by fluctuations in the river stage along the Hanford reach between the area west of the 100-B and 100-C Areas and the 300 Area.. 
- The elevation of the water table beneath the 100-N Area and southwest of the 100-N Area decreased as much as $0.34 \mathrm{~m}(1.1 \mathrm{ft})$ between December 1990 and December 1991, primarily the result of decreasing discharge to wastewater facilities in the 100-N Area.

Water levels were also monitored in the unconfined aquifer north and east of the Columbia River in agricultural areas during 1991. Water-level data indicate that recharge from irrigation practices continues to heavily influence the configuration of the water table in these areas. However, the steep hydraulic gradients, as indicated by the data, are primarily controlled by the configuration of the basalt surface, hydrogeologic characteristics of the unconfined aquifer sediments, and topographic features. 


\section{REFERENCES}

Airhart, S. P. 1990. Borehole Completion Data Package for the 216-S-10 Ditch and Pond. WHC-MR-0206, Westinghouse Hanford Company, Richland, Washington.

ASTM. 1988. "Standard Method for Determining Subsurface Liquid Levels in a Borehole or Monitoring Well (Observation We11)." D 4750-87, American Society for Testing and Materials, Philadelphia, Pennsylvania.

Bauer, H. H., J. J. Vaccaro, and R. C. Lane. 1985. Maps Showing Ground-Water Levels in the Columbia River Basalt and Overlying Materials, Spring 1983, Southeastern. Washington. Water-Resources Investigations Report 84-4360, U.S. Geological Survey, Tacoma, Washington.

Brown, R. E. 1979. A Review of Water-Well Data From the Unconfined Aquifer in the Eastern and Southern Parts of the Pasco Basin. RHO-BWI-C-56, Rockwe 11 Hanford Operations, Richland, Washington.

Brown, M. J., R. K. P'Pool, and S. P. Thomas. 1990. Westinghouse Hanford Company Effluent Discharges and Solid Waste Management Report for Calendar Year 1989: 200/600 Areas. WHC-EP-0141-2, Westinghouse Hanford Company, Richland, Washington.

DOE (U.S. Department of Energy). 1988. Consultation Draft, Site Characterization Plan. Reference Repository Location, Hanford Site, Washington. DOE/RW0164, Vo1. 1, U.S. Department of Energy, Washington, D.C.

Drost, B. W., K. M. Schurr, and W. E. Lum II. 1989. Selected Ground-Water Information for the Pasco Basin and Adjacent Areas, Washington, 1986-1989. Open-File Report 89-228, U.S. Geological Survey, Tacoma, Washington.

EPA. 1986. Resource Conservation and Recovery Act (RCRA) Ground-Water Monitoring Technical Enforcement Guidance Document. OWSER-9950.1, U.S. Environmental Protection Agency, Washington, D.C.

Fruland, R. M., and R. E. Lundgren, eds. 1989. RCRA Ground-Water Monitoring Projects for Hanford Facilities: Annual Progress Report for 1988. PNL-6852, Pacific Northwest Laboratory, Richland, Washington.

Garber, M. S., and F.C. Koopman. 1968. Methods of Measuring Water Levels in Deep Wells: U.S. Geological Survey TRWI, Book 8, Chap. A-1. U.S. Government Printing Office, Washington, D.C.

Gephart, R. E., R. C. Arnett, R. G. Baca, L. S. Leonhart, and F. A. Spane, Jr. 1979. Hydrologic Studies Within the Columbia Plateau, Washington: An Integration of Current Knowledge. RHO-BWI-ST-5, Rockwell Hanford Operations, Richland, Washington.- 
Graham, M. J., M. D. Hal1, S. R. Strait, and W. R. Brcwn. 1981. Hydrology of the Separations Area. RHO-ST-42, Rockwell Hanford Operations, Richland, Washington.

Grolier, M. J., and J. W. Bingham. 1978. Geology of Parts of Grant, Adams, and Frankl in Counties, East-Central Washington. Bulletin No. 71, Department of Natural Resources, State of Washington, OTympia, Washington.

ICF. 1987. Hydrogeologic Study of North Richland Well Field and Ground-water Recharge Basins. Prepared by ICF Nortliwest for the City of Richland, Washington.

Jensen, E. J. 1987. Summary of Water-Level Measurements Around the 1325:N Crib During the Fall of 1985 and the Winter of 1986-1987. PNL-6374, Pacific Northwest Laboratory, Richland, Washington.

Kasza, G. L., M. J. Hartman, and F. N. Hodges. 1991a. Ground Water Maps of the Hanford Site, December 1990. WHC-EP-0394-2, West inghouse Hanford Company, Richland, Washington.

Kasza, G. L., M. J. Hartman, F. N. Hodges, and D. C. Weekes. 1991b. Ground Water Maps of the Hanford Site, June 1991. WHC-EP-0394-3, Westinghouse Hanford Company, Richland, Washington.

Liikala, T. L., R. L. Aaberg, N. J. Aimo, D. J. Bates, T. J Gilmore, E. J. Jensen, G. V. Last, P. L. Oberlander, K. B. 01 sen, K. R. Oster, L. R. Roome, J. C. Simpson, S. S. Teel, and E. J. Westergard. 1988. Geohydrologic Characterization of the Area Surrounding the $183-\mathrm{H}$ Solar Evaporation Basins. PNL-6728, Pacific Northwest Laboratory, Richland, Washington.

McGhan, V. L. 1989. Hanford Wells. PNL-6907, Pacific Northwest Laboratory, Richland, Washington.

Myers, C. W., S. M. Price, J. A. Caggiano, M. P. Cochran, W. J. Czimer, N. J. Davidson, R. C. Edwards, K. R. Fecht, G. E. Holmes, M. G. Jones, J. R. Kunk, R. D. Landon, R. K. Ledgerwood, J. T. Lillie, P. E. Long, T. H. Mitchell, E. H. Price, S. P. Riedel, and A. M. Tallman. 1979. Geologic Studies of the Columbia Plateau: A Status Report. RHO-BWI-ST-4, Rockwell Hanford Operations, Richland, Washington.

Newcomb, R. C., J. R. Strand, and F. J. Frank. 1972. Geology and GroundWater Characteristics of the Hanford Reservation of the U.S. Atomic Energy Commission, Washington. Professional Paper 717, U.S. Geological Survey, Washington, D.C.

Newcomer, D. R. 1990. Evaluation of Hanford Site Water-Table Changes - 1980 to 1990. PNL-7498, Pacific Northwest Laboratory, Richland, Washington.

Newcomer, D. R., and J. P. McDonald. 1990. Water-Table Elevations on the Hanford Site, December 1989. PNL-7374, Pacific Northwest Laboratory, Richland, Washington. 
Newcomer, D. R., K. D. Pohlod, and J. P. McDonald. 1991. Water-Table Elevations on the Hanford Site, 1990. PNL-7693, Pacific Northwest Laboratory, Richland, Washington.

PNL. 1989. Procedures for Ground-Water Investigations. PNL-6894, Pacific Northwest Laboratory, Richland, Washington.

RHO. 1984. Unconfined Aquifer Water-Table Map - June 1984. H-2-38396, Rev. 17, Rockwell Hanford Operations, Richland, Washington.

Schalla, R., R. W. Wallace, R. L. Aaberg, S. P. Airhart, D. J. Bates, J. V. M. Carlile, C. S. Cline, D. I. Dennison, M. D. Freshley, P. R. Heller, E. J. Jensen, K. B. 01 sen, R. G. Parkhurst, J. T. Rieger, and E. J. Westergard. 1988. Interim Characterization Report for the 300 Area Process Trenches. PNL-6716, Pacific Northwest Laboratory, Richland, Washington.

USGS. 1977. National Handbook of Recommended Methods for Water Data Acquisition. U.S. Geological Survey, Office of Water Data Coordination, Reston, Virginia.

Walters, K. L., and M. J. Grolier. 1960. Geology and Ground Water Resources of the Columbia Basin Project Area, Washington Volume I, Division of Water Resources, State of Washington, Olympia, Washington.

WHC. 1989. Environmental Investigations and Site Characterization Manual. WHC-CM-7-7, vol. 1, Westinghouse Hanford Company, Richland, Washington.

Zimmerman, D. A., A. E. Reisenauer, G. D. Black, and M. A. Young. 1986. Hanford Site Water Table Changes 1950 Through 1980 - Data Observations and Evaluation. PNL-5506, Pacific Northwest Laboratory, Richland, Washington. 
APPENDIX A

WATER-LEVEL MEASUREMENTS FOR THE HANFORD SITE AND OUTLYING AREAS, JUNE - AUGUST 1991 
APPENDIX A

WATER-LEVEL MEASUREMENTS FOR THE HANFORD SITE AND OUTLYING AREAS,

JUNE - AUGUST 1991.

TABLE A.1. Water-Level Measurements from Unconfined Aquifer Wells on the Hanford Site Proper, June 1991 (measured by PNL except as noted)

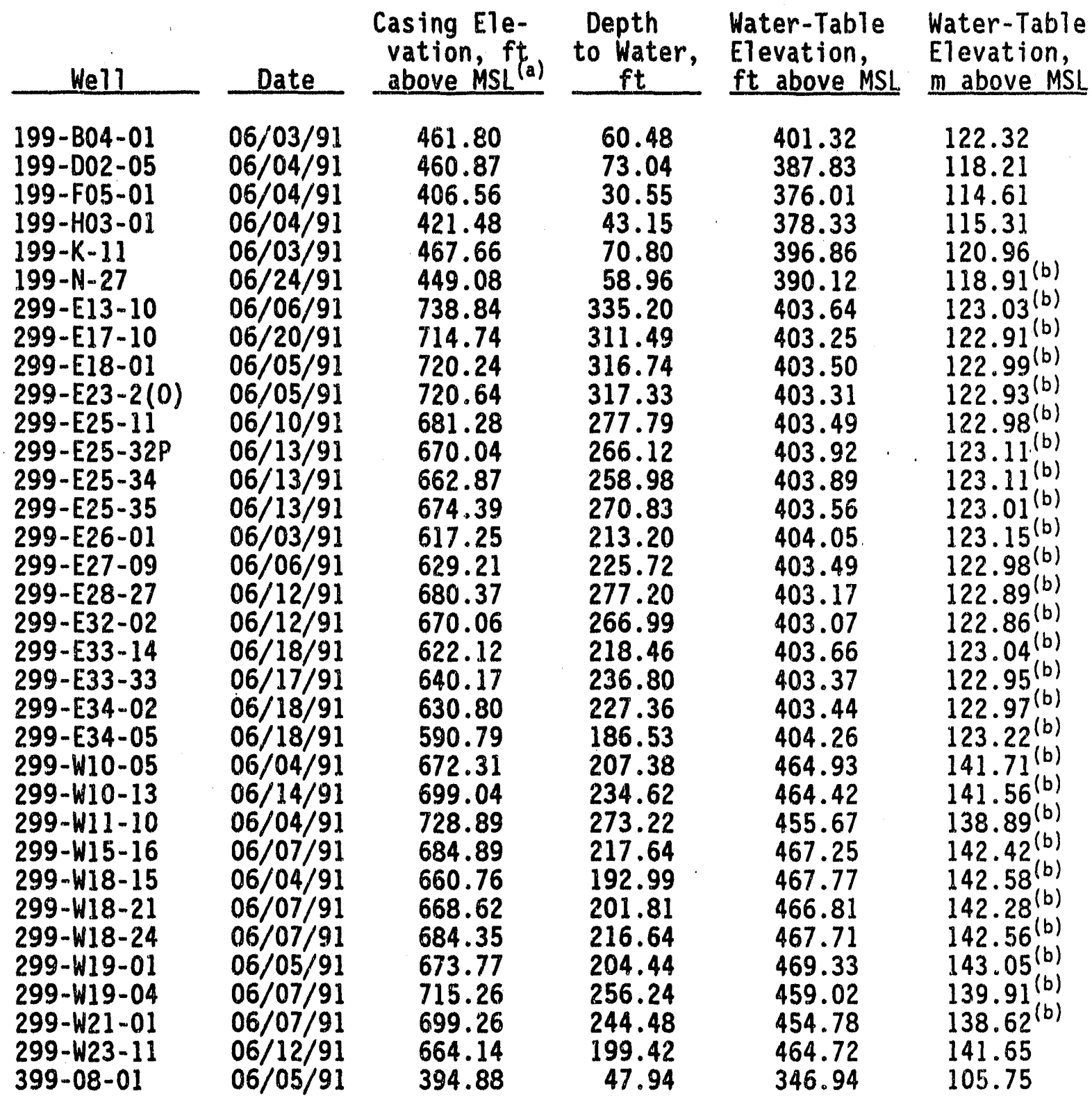


TABLE A.1. (contd)

\begin{tabular}{|c|c|c|c|c|c|}
\hline We 11 & Date & $\begin{array}{l}\text { Casing Ele- } \\
\text { vation, } f t_{(a)} \\
\text { above MSL } \\
\end{array}$ & $\begin{array}{c}\text { Depth } \\
\text { to Water, } \\
\mathrm{ft} \\
\end{array}$ & $\begin{array}{l}\text { Water-Table } \\
\text { Elevation, } \\
\text { ft above MSL }\end{array}$ & $\begin{array}{l}\text { Water-Table } \\
\text { Elevation, } \\
\text { m above MSL }\end{array}$ \\
\hline $\begin{array}{l}699-02-03 \\
699-02-33 A \\
699-03-45 \\
699-08-17 \\
699-08-25 \\
699-08-32 \\
699-09-E 02 \\
699-10-54 B \\
699-10-E 12 \\
699-11-45 A \\
699-14-38 \\
699-14-47 \\
699-15-15 A \\
699-15-26 \\
699-17-05 \\
699-17-70 \\
699-19-43 \\
699-19-58 \\
699-19-88 \\
699-20-20 \\
699-20-39 \\
699-20-E 12 \\
699-21-17 \\
699-24-01 T \\
699-24-33 \\
699-25-55 \\
699-25-70 \\
699-26-15 A \\
699-26-89 \\
699-27-08 \\
699-28-40 \\
699-28-52 A \\
699-29-78 \\
699-31-31 \\
699-32-22 A \\
699-32-43 \\
699-32-62 \\
699-32-70 B \\
699-32-72 \\
699-32-77 \\
699-33-56 \\
699-34-39 A \\
699-34-41 B \\
699-34-42\end{array}$ & $\begin{array}{l}06 / 20 / 91 \\
06 / 19 / 91 \\
06 / 18 / 91 \\
06 / 19 / 91 \\
00 / 19 / 91 \\
06 / 19 / 91 \\
06 / 20 / 91 \\
06 / 12 / 91 \\
06 / 05 / 91 \\
06 / 12 / 91 \\
06 / 19 / 91 \\
06 / 12 / 91 \\
06 / 07 / 91 \\
06 / 19 / 91 \\
06 / 20 / 91 \\
06 / 18 / 91 \\
06 / 12 / 91 \\
06 / 12 / 91 \\
06 / 18 / 91 \\
06 / 19 / 91 \\
06 / 12 / 91 \\
06 / 05 / 91 \\
06 / 19 / 91 \\
06 / 20 / 91 \\
06 / 13 / 91 \\
06 / 06 / 91 \\
06 / 12 / 91 \\
06 / 19 / 91 \\
06 / 18 / 91 \\
06 / 21 / 91 \\
06 / 13 / 91 \\
06 / 06 / 91 \\
06 / 12 / 91 \\
06 / 13 / 91 \\
06 / 13 / 91 \\
06 / 27 / 91 \\
06 / 07 / 91 \\
06 / 07 / 91 \\
06 / 07 / 91 \\
06 / 07 / 91 \\
06 / 06 / 91 \\
06 / 13 / 91 \\
06 / 27 / 91 \\
06 / 26 / 91\end{array}$ & $\begin{array}{l}477.14 \\
536.37 \\
504.54 \\
522.44 \\
509.30 \\
554.39 \\
418.09 \\
516.20 \\
430.86 \\
578.58 \\
514.89 \\
587.23 \\
547.14 \\
523.83 \\
433.19 \\
563.18 \\
551.58 \\
573.05 \\
644.45 \\
505.58 \\
539.98 \\
437.25 \\
527.31 \\
475.54 \\
524.21 \\
676.55 \\
629.78 \\
442.64 \\
653.08 \\
465.67 \\
559.44 \\
684.67 \\
647.05 \\
529.32 \\
517.55 \\
516.62 \\
707.09 \\
666.68 \\
668.16 \\
653.74 \\
717.03 \\
537.07 \\
570.89 \\
540.20\end{array}$ & $\begin{array}{r}86.47 \\
132.34 \\
92.65 \\
123.75 \\
109.42 \\
153.99 \\
45.92 \\
103.05 \\
73.22 \\
166.79 \\
110.11 \\
175.23 \\
148.37 \\
122.65 \\
44.86 \\
88.76 \\
147.33 \\
154.03 \\
130.99 \\
104.34 \\
136.43 \\
79.22 \\
129.96 \\
98.98 \\
121.55 \\
263.47 \\
181.68 \\
44.18 \\
180.59 \\
71.44 \\
156.26 \\
279.91 \\
184.30 \\
126.62 \\
116.76 \\
113.27 \\
278.29 \\
215.66 \\
215.01 \\
192.71 \\
312.56 \\
133.80 \\
167.48 \\
136.75\end{array}$ & $\begin{array}{l}390.67 \\
404.03 \\
411.89 \\
398.69 \\
399.88 \\
400.40 \\
372.17 \\
413.15 \\
357.64 \\
411.79 \\
404.78 \\
412.00 \\
398.77 \\
401.18 \\
388.33 \\
474.42 \\
404.25 \\
419.02 \\
513.46 \\
401.24 \\
403.55 \\
358.03 \\
397.35 \\
376.56 \\
402.66 \\
413.08 \\
448.10 \\
398.46 \\
472.49 \\
394.23 \\
403.18 \\
404.76 \\
462.75 \\
402.70 \\
400.79 \\
403.35 \\
428.80 \\
451.02 \\
453.15 \\
461.03 \\
404.47 \\
403.27 \\
403.41 \\
403.45\end{array}$ & $\begin{array}{l}119.08 \\
123.15 \\
125.54 \\
121.52 \\
121.88 \\
122.04 \\
113.44 \\
125.93 \\
109.01 \\
125.51 \\
123.38 \\
125.58 \\
121.55 \\
122.28 \\
118.36 \\
144.60 \\
123.22 \\
127.72 \\
156.50 \\
122.30 \\
123.00 \\
109.13 \\
121.11 \\
114.78 \\
122.73 \\
125.91 \\
136.58 \\
121.45 \\
144.01 \\
120.16 \\
122.89 \\
123.37(b) \\
141.05 \\
122.74 \\
122.16 \\
122.94 \\
130.70 \\
137.47 \\
138.12 \\
140.52 \\
123.28(b) \\
122.92 \\
122.96 \\
122.97 \\
\end{array}$ \\
\hline
\end{tabular}

\begin{tabular}{rlll}
$\begin{array}{c}\text { Casing Ele- } \\
\text { vation, } f f_{(}\end{array}$to Water, & $\begin{array}{l}\text { Water-Table } \\
\text { Elevation, }\end{array}$ & $\begin{array}{l}\text { Water-Table } \\
\text { Elevation, } \\
\text { above MSL }\end{array}$ \\
\hline
\end{tabular} 
TABLE A.1. (contd)

Casing Ele- Depth Water-Table Water-Table

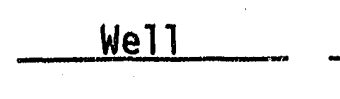

$699-34-51$
$699-34-88$
$699-35-09$
$699-35-66$
$699-35-70$
$699-35-78 A$

699-36-61A

699-36-93

699-37-43

699-37-82A

699-38-65

699-38-70

699-39-39

699-39-79

699-40-01

699-40-33A

699-40-62

699-41-23

699-42-12A

699-42-40B

$699-43-42$

699-43-89

699-43-104

699-44-64

699-45-42.

699-45-69A

699-46-21B

699-47-35A

$699-47-46 A$

699-47-60

699-48-07

699-48-71

699-49-13E

699-49-28

$699-49-79$

699-50-30

699-50-42

699-50-53

699-50-85

699-51-63

699-51-75

699-52-19

699-53-35

$699-53-48 B$
Date

$06 / 06 / 91$

$06 / 13 / 91$

$06 / 21 / 91$

$06 / 27 / 91$

$06 / 07 / 91$

$06 / 07 / 91$

$06 / 07 / 91$

$06 / 18 / 91$

$06 / 13 / 91$

$06 / 07 / 91$

$06 / 07 / 91$

$06 / 07 / 91$

$06 / 24 / 91$

06/04/91

06/04/91

$06 / 13 / 91$

$06 / 06 / 91$

$06 / 27 / 91$

$06 / 21 / 91$

$06 / 24 / 91$

$06 / 24 / 91$

$06 / 12 / 91$

$06 / 18 / 91$

$06 / 06 / 91$

$06 / 07 / 91$

$06 / 06 / 91$

$06 / 27 / 91$

$06 / 24 / 91$

$06 / 27 / 91$

$06 / 06 / 91$

06/04/91

$06 / 06 / 91$

06/05/9i

$06 / 19 / 91$

$06 / 06 / 91$

$06 / 11 / 91$

$06 / 11 / 91$

$06 / 21 / 91$

$06 / 06 / 91$

$06 / 06 / 91$

$06 / 06 / 91$

$06 / 05 / 91$

$06 / 10 / 91$

$06 / 11 / 91$ vation, $f$

above MSL (a)

736.76

632.82

499.83

725.65

693.72

660.65

748.11

644.77

690.17

636.75

753.33

710.67

536.65

673.52

438.71

518.05

747.78

466.50

514.27

546.46

566.36

644.15

766.07

725.60

577.33

725.46

522.02

476.36

580.14

649.84

384.72

688.15

412.72

535.40

689.20

528.84

466.84

556.30

739.35

571.84

641.51

411.08

530.99

442.71 to Water, $\mathrm{ft}$

332.99

163.57

113.72

286.56

242.74

194.93

339.84

173.03

285.99

169.92

323.29

258.13

123.56

207.15

74.20

106.95

341.68

68.39

137.82

123.71

145.19

177.74

267.32

318.55

160.23

277.75

130.56

62.31

175.38

246.63

20.95

242.14

49.38

141.03

232.43

134.28

55.61

153.22

283.72

166.38

191.74

47.84

131.70

38.51
Elevation, ft above MSL $m$ above MSL

403.77

469.25

386.11

439.09

450.98

465.72

408.27

471.74

404.18

466.83

430.04

452.54

413.09

466.37

364.51

411.10

406.10

398.11

376.45

422.75

421.17

466.41

498.75

407.05

417.10

447.71

391.46

414.05

404.76

403.21

363.77

446.01

363.34

394.37

456.77

394.56

411.23

403.08

455.63

405.46

449.77

363.24

399.29

404.20 $123.07^{(b)}$

143.03

117.69

133.83

137.46

141.95

124.44

143.79

123.19

142.29

131.08

137.93

125.91

$142.15^{(b)}$

111.10

125.30

123.78

121.34

114.74

128.85

128.37

142.16

152.02

124.07

$127.13^{(b)}$

136.46

119.32

126.20

123.37

122.90

110.88

135.94

110.75

120.20

139.22

120.26

125.34

122.86

138.88

123.58

137.09

110.72

121.70

123.20 
TABLE A.1. (contd)

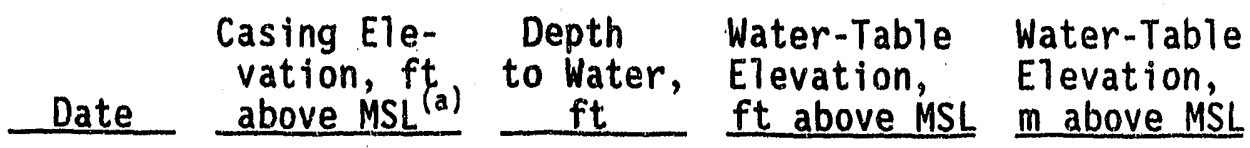
\begin{tabular}{cccc}
$\begin{array}{c}\text { Casing Ele- } \\
\text { vation, ft }\end{array}$ Depth & Water-Table & Water-Table \\
above MSL (a) & $\mathrm{ft}$ & $\begin{array}{l}\text { Elevation, } \\
\text { ft above MSL m mabove MSL }\end{array}$ \\
\hline
\end{tabular} We11 $699-53-55 \mathrm{C}$ 699-54-19 699-54-34 699-54-37A 699-54-42 699-54-45A 699-54-48 699-55-21 699-55-40 699-55-44 699-55-50C 699-55-70 699-55-76 699-55-89 699-55-95 699-56-43 699-57-25A 699-57-29B 699-57-83A 699-58-24 $699-59-32$ 699-59-58 699-59-80B $699-60-32$ $699-60-60$ $699-61-37$ 699-61-41 699-61-62 699-61-66 699-62-31 699-62-43A 699-63-25A 699-63-51 $699-63-58$ 699-63-90 699-64-27 699-64-62 $699-65-50$ 699-65-59A 699-65-72 699-65-83 699-65-95 699-66-23 699-66-38

\section{$06 / 10 / 91$}

$06 / 05 / 91$

$06 / 10 / 91$

$06 / 10 / 91$

$06 / 11 / 91$

$06 / 11 / 91$

$06 / 11 / 91$

$06 / 05 / 91$

$06 / 10 / 91$

$06 / 10 / 91$

$06 / 05 / 91$

$06 / 06 / 91$

06/06/91

06/06/91

$06 / 03 / 91$

$06 / 10 / 91$

06/05/91

$06 / 26 / 91$

06/06/91

06/05/91

$06 / 26 / 91$

$06 / 03 / 91$

06/06/91

$06 / 26 / 91$

$06 / 10 / 91$

$06 / 26 / 91$

$06 / 26 / 91$

$06 / 10 / 91$

$06 / 10 / 91$

$06 / 26 / 91$

$06 / 26 / 91$

$06 / 04 / 91$

$06 / 26 / 91$

$06 / 10 / 91$

$06 / 03 / 91$

06/04/91

$06 / 10 / 91$

$06 / 26 / 91$

$06 / 14 / 91$

$06 / 03 / 91$

$06 / 03 / 91$

$06 / 03 / 91$

$06 / 04 / 91$

$06 / 26 / 91$

576.08
383.60
550.24
534.17
511.49
494.29
457.02
395.96
543.13
519.67
444.43
569.03
583.24
617.43
777.05
540.42
414.57
416.18
577.96
418.80
424.29
497.77
583.25
425.30
512.03
442.94
428.92
497.51
522.18
434.12
432.30
395.15
424.54
491.90
509.73
414.29
500.25
467.06
506.96
540.28
485.63
452.26
389.01
436.24

173.37

20.28

140.45

124.79

115.34

Dry Well - No Measurement

54.34

33.87

133.37

124.11

41.84

136.68

138.86

162.79

311.37

131.39

48.99

52.49

144.97

55.54

60.35

95.98

153.97

61.35

109.46

60.96

32.71

94.95

120.19

70.40

35.76

31.98

24.23

90.31

107.08

51.11

98.71

66.74

105.58

139.48

84.94

47.85

21.37

33.46 $\begin{array}{ll}402.71 & 122.75 \\ 363.32 & 110.74 \\ 409.79 & 124.90 \\ 409.38 & 124.78 \\ 396.15 & 120.75\end{array}$

$\begin{array}{ll}402.68 & 122.74\end{array}$

$362.09 \quad 110.37$

$409.76 \quad 124.89$

$395.56 \quad 120.57$

$402.59 \quad 122.71^{(b)}$

$432.35 \quad 131.78$

$444.38 \quad 135.45$

$454.64 \quad 138.57$

$465.68 \quad 141.94$

$409.03 \quad 124.67$

$365.58 \quad 111.43$

$363.69 \quad 110.85$

$432.99 \quad 131.98$

$363.26 \quad 110.72$

$363.94 \quad 110.93$

$401.79 \quad 122.47$

$429.28 \quad 130.84$

$363.95 \quad 110.93$

$402.57 \quad 122.70$

$381.98 \quad 116.43$

$396.21 \quad 120.76$

$402.56 \quad 122.70$

$401.99 \quad 122.53$

$363.72 \quad 110.86$

$396.54 \quad 120.87$

$363.17 \quad 110.69$

$400.31 \quad 122.01$

$401.59 \quad 122.40$

$402.65 \quad 122.73$

$363.18 \quad 110.70$

$401.54 \quad 122.39$

$400.32 \quad 122.02$

$401.38 \quad 122.34$

$400.80 \quad 122.16$

$400.69 \quad 122.13$

$404.41 \quad 123.26$

$367.64 \quad 112.06$

$\begin{array}{ll}402.78 & 122.77\end{array}$ 
TABLE A.1. (contd)

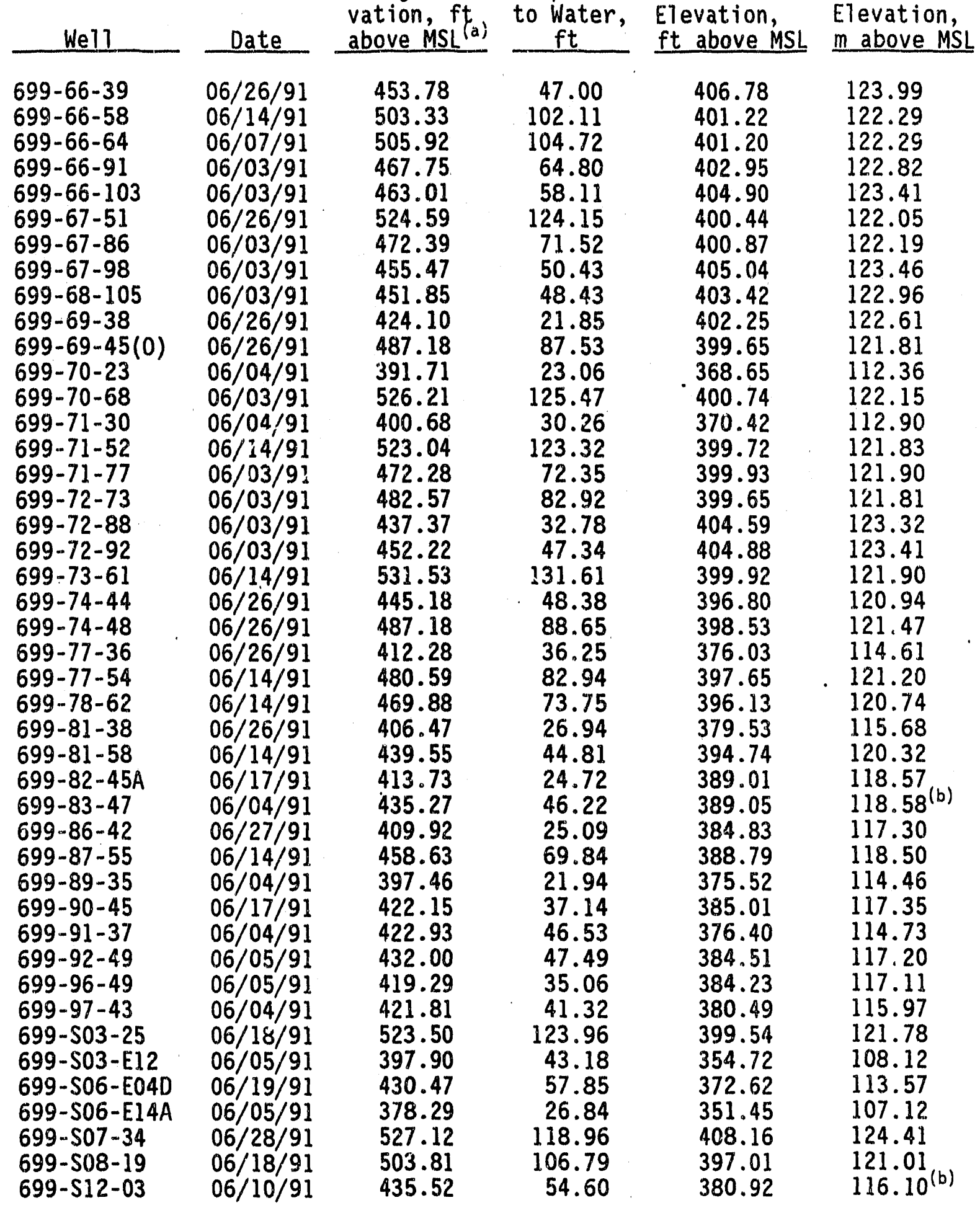


IABLE A.l. (contd)

\begin{tabular}{|c|c|c|c|c|c|}
\hline Nell & Date & $\begin{array}{l}\text { Casing Ele- } \\
\text { vation, fta } \\
\text { above MSL } \\
\end{array}$ & $\begin{array}{l}\text { Depth } \\
\text { to hlater, } \\
\text { fit }\end{array}$ & $\begin{array}{l}\text { Water-Table } \\
\text { Elevation, } \\
\text { ft above MSL }\end{array}$ & $\begin{array}{l}\text { Water-Table } \\
\text { Elevation, } \\
\text { m above MSL }\end{array}$ \\
\hline $\begin{array}{l}699-S 12-29 \\
699-S 14-20 A \\
699-S 18-E .02 A \\
699-S 19-11 \\
699-S 19-E 13 \\
699-S 29-E 12 \\
699-S 30-E 15 A \\
699-S 31-01 \\
699-S 31-E 08 \\
699-S 34-E 10 \\
699-S 37-E 14 \\
699-S 38-E 11 \\
699-S 40-E 14 \\
699-S 43-E 12 \\
1199-34-13 \\
3099-45-16\end{array}$ & $\begin{array}{l}06 / 18 / 91 \\
06 / 18 / 91 \\
06 / 12 / 91 \\
06 / 24 / 91 \\
06 / 05 / 91 \\
06 / 05 / 91 \\
06 / 05 / 91 \\
05 / 17 / 91 \\
06 / 17 / 91 \\
06 / 13 / 91 \\
06 / 17 / 91 \\
06 / 17 / 91 \\
06 / 17 / 91 \\
06 / 17 / 91 \\
06 / 17 / 91 \\
06 / 17 / 91\end{array}$ & $\begin{array}{l}487.68 \\
492.74 \\
434.85 \\
483.74 \\
394.51 \\
387.96 \\
400.14 \\
460.00 \\
374.75 \\
302.37 \\
408.28 \\
398.60 \\
402.85 \\
405.60 \\
394.78 \\
408.04\end{array}$ & $\begin{array}{l}83.22 \\
91.88 \\
75.45 \\
93.83 \\
46.99 \\
41.48 \\
54.49 \\
84.08 \\
21.45 \\
29.23 \\
52.83 \\
431.61 \\
44.43 \\
51.57 \\
41 . .50 \\
513.51\end{array}$ & $\begin{array}{l}404.46 \\
400.86 \\
359.40 \\
389.91 \\
347.52 \\
346.48 \\
345.65 \\
375.92 \\
353.30 \\
353.14 \\
355.45 \\
354.99 \\
358.42 \\
354.03 \\
352.28 \\
349.53\end{array}$ & $\begin{array}{l}123.28 \\
122.18 \\
109.55(b) \\
118.84 \\
105.92 \\
105.51 \\
105.35 \\
114.58 \\
107.69 \\
107.64 \\
108.34 \\
108.20 \\
109.25 \\
107.91 \\
.47 .37 \\
106.54\end{array}$ \\
\hline
\end{tabular}

(a) MSL = mean sea level.

(b) Measured by Hestinghouse Hanford Company. 
IABLE A.2. Water-Level Measurements from Unconfined Aquifer Wells North and East of the Columbia River, July - August 1991 (measured by U.S. Bureau of Reclamation)

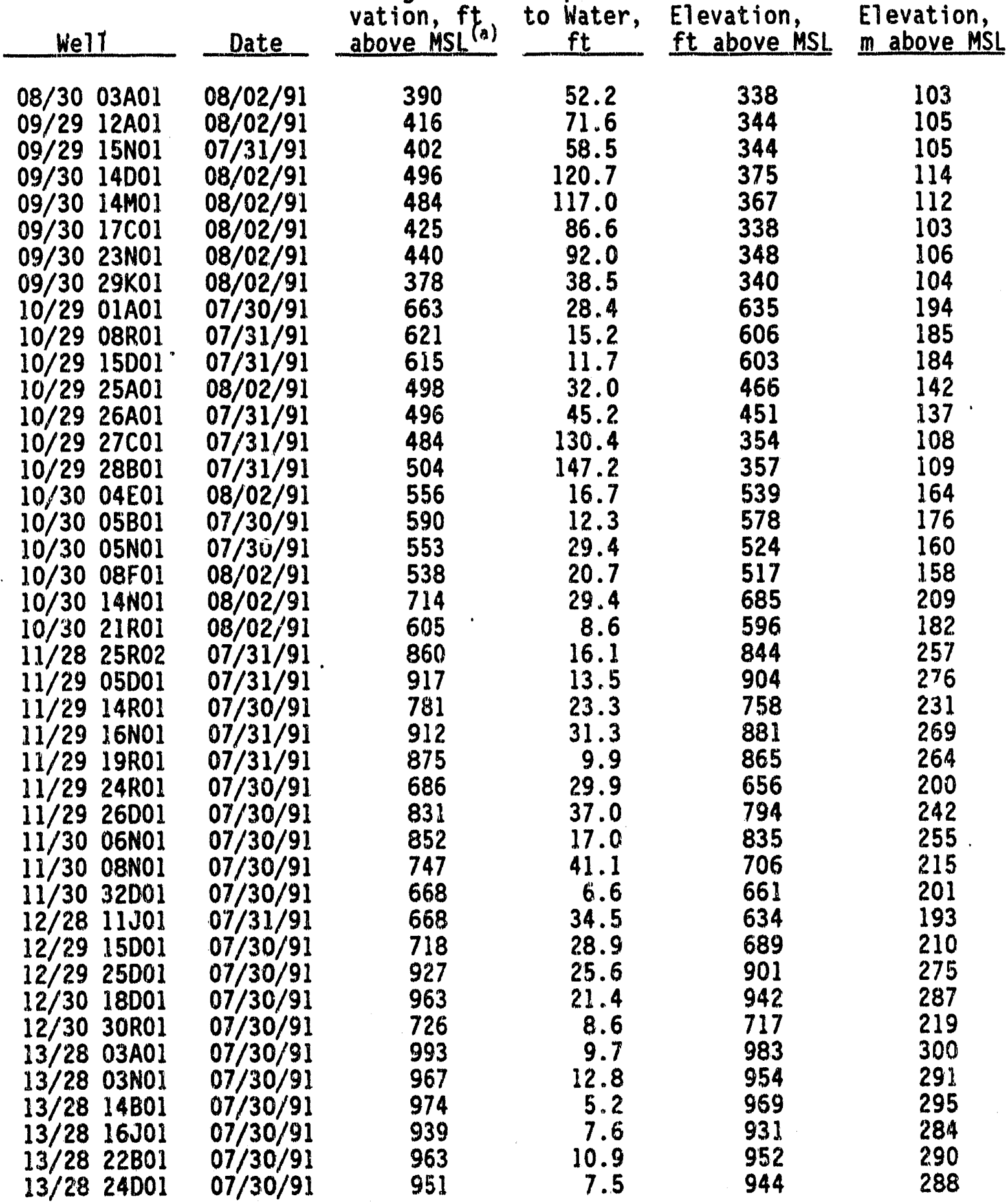


IABLE A.2. (contd)

\begin{tabular}{|c|c|c|c|c|c|}
\hline Well & Date & $\begin{array}{l}\text { Casing Ele- } \\
\text { vation, } f t_{(a)} \\
\text { above MSL }\end{array}$ & $\begin{array}{l}\text { Depth } \\
\text { to Water, } \\
\mathrm{ft} \\
\end{array}$ & $\begin{array}{l}\text { Water-Table } \\
\text { Elevation, } \\
\text { ft above MSL }\end{array}$ & $\begin{array}{l}\text { Water-Table } \\
\text { Elevation, } \\
\text { m above MSL } \\
\end{array}$ \\
\hline 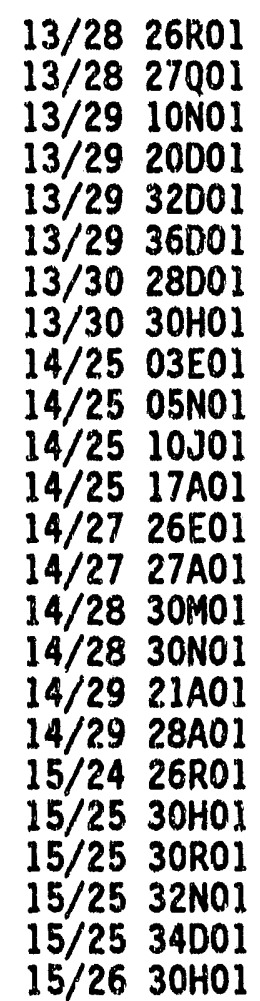 & $\begin{array}{l}07 / 30 / 91 \\
07 / 30 / 91 \\
07 / 30 / 91 \\
07 / 30 / 91 \\
07 / 30 / 91 \\
07 / 30 / 91 \\
07 / 30 / 91 \\
07 / 30 / 91 \\
08 / 08 / 91 \\
08 / 08 / 91 \\
08 / 08 / 91 \\
08 / 08 / 91 \\
07 / 26 / 91 \\
07 / 26 / 91 \\
07 / 26 / 91 \\
07 / 26 / 91 \\
07 / 30 / 91 \\
07 / 30 / 91 \\
08 / 08 / 91 \\
08 / 08 / 91 \\
08 / 08 / 91 \\
08 / 08 / 91 \\
08 / 08 / 91 \\
08 / 08 / 91\end{array}$ & $\begin{array}{l}941 \\
928 \\
950 \\
992 \\
951 \\
771 \\
892 \\
857 \\
675 \\
731 \\
640 \\
687 \\
680 \\
683 \\
733 \\
736 \\
1013 \\
926 \\
897 \\
866 \\
811 \\
761 \\
789 \\
854\end{array}$ & $\begin{array}{r}9.7 \\
10.4 \\
48.9 \\
7.8 \\
16.4 \\
34.6 \\
24.2 \\
13.7 \\
11.7 \\
33.3 \\
60.0 \\
39.8 \\
13.0 \\
14.7 \\
11.9 \\
10.3 \\
31.0 \\
11.3 \\
37.8 \\
43.0 \\
20.0 \\
32.5 \\
38.6 \\
30.4\end{array}$ & $\begin{array}{l}931 \\
918 \\
901 \\
984 \\
935 \\
736 \\
868 \\
843 \\
663 \\
698 \\
580 \\
648 \\
667 \\
668 \\
721 \\
726 \\
982 \\
915 \\
859 \\
823 \\
791 \\
729 \\
750 \\
824\end{array}$ & $\begin{array}{l}284 \\
280 \\
275 \\
300 \\
285 \\
224 \\
265 \\
257 \\
202 \\
213 \\
177 \\
198 \\
203 \\
204 \\
220 \\
221 \\
299 \\
279 \\
262 \\
251 \\
241 \\
222 \\
229 \\
251\end{array}$ \\
\hline
\end{tabular}

(a) MSL = mean sea level. 
APPENDIX B

WATER-LEVEL MEASURMENTS FOR THE HAMFORD SITE PROPER, DECEMBER 1991 
WATER-LEVEL MEASURMENTS FOR THE HANFORD SITE PROPER, DECEMBER 1991

TABLE B.1. Water-Level Measurements from Unconfined Aquifer Wells on the Hanford Site Paper, December 1991 (measured by Westinghouse Hanford Company except as noted)

\begin{tabular}{|c|c|c|c|c|c|}
\hline Well & Date & $\begin{array}{l}\text { Casing Ele- } \\
\text { vation, ft } \\
\text { above } M S_{L}(a) \\
\end{array}$ & $\begin{array}{l}\text { Depth } \\
\text { to Water, } \\
\mathrm{ft} \\
\end{array}$ & $\begin{array}{r}\text { Water-Tabie } \\
\text { Elevation, } \\
\text { ft above MSL } \\
\end{array}$ & $\begin{array}{r}\text { Water-Table } \\
\text { Elevation, } \\
\text { m above MSL } \\
\end{array}$ \\
\hline $\begin{array}{l}199-N-27 \\
199-N-60 \\
299-W 10-13 \\
299-W 18-15 \\
299-W 18-21 \\
299-W 19-01 \\
399-08-01 \\
699-39-39 \\
699-40-39 \\
699-41-40 \\
699-42-40 B \\
699-81-58 \\
699-S 31-01 \\
699-S 31-01 \\
699-540-E 14 \\
1199-34-13 \\
E C-1\end{array}$ & $\begin{array}{l}12 / 16 / 91 \\
12 / 17 / 91 \\
12 / 12 / 91 \\
12 / 11 / 91 \\
12 / 06 / 91 \\
12 / 11 / 91 \\
12 / 18 / 91 \\
12 / 13 / 91 \\
12 / 13 / 91 \\
12 / 13 / 91 \\
12 / 11 / 91 \\
12 / 16 / 91 \\
12 / 20 / 91 \\
12 / 26 / 91 \\
01 / 03 / 92 \\
12 / 20 / 91 \\
12 / 20 / 91\end{array}$ & $\begin{array}{l}449.08 \\
461.94 \\
699.04 \\
660.76 \\
668.62 \\
673.77 \\
394.88 \\
536.65 \\
541.84 \\
545.94 \\
546.46 \\
439.55 \\
460.00 \\
460.00 \\
402.85 \\
394.78 \\
362.57\end{array}$ & $\begin{array}{r}60.34 \\
72.69 \\
234.83 \\
193.25 \\
202.02 \\
204.43 \\
51.76 \\
124.78 \\
129.01 \\
130.97 \\
125.43 \\
45.28 \\
81.20 \\
84.01 \\
51.55 \\
41.60 \\
5.40\end{array}$ & $\begin{array}{r}388.74 \\
389.25 \\
464.21 \\
467.51 \\
466.6 \\
469.34 \\
343.12 \\
411.87 \\
412.83 \\
414.97 \\
421.03 \\
394.27 \\
378.80 \\
375.99 \\
351.30 \\
353.18 \\
357.17\end{array}$ & $\begin{array}{l}118.49 \\
118.64 \\
141.49 \\
142.50 \\
142.22 \\
143.05 \\
104.58 \\
125.54 \\
125.83 \\
126.48 \\
128.33 \\
120.17 \\
115.46 \\
114.60 \\
107.08^{(b)} \\
107.65^{(b)} \\
108.87^{(b)}\end{array}$ \\
\hline
\end{tabular}

(a) MSL = mean sea level.

(b) Measured by PNL. 
APPENDIX C

WATER-LEVEL MEASURMENTS AT SPECIFIC HANFORD SITE AREAS, JUNE 1991 


\section{APPENDIX C}

WATER-LEVEL MEASURMENTS AT SPECIFIC HANFORD SITE AREAS, JUNE 1991

TABLE C.1. 216-B-3 Pond Water-Leve1 Measurements in Unconfined Aquifer We11s, June 1991 (measured by Westinghouse Hanford Company)

\begin{tabular}{|c|c|c|c|c|c|}
\hline Hell & Date & $\begin{array}{c}\text { Casing } \\
\text { Elevation, } \\
\text { ft above } M S L^{(a)} \\
\end{array}$ & $\begin{array}{l}\text { Depth to } \\
\text { Water, } \\
\text { ft } \\
\end{array}$ & $\begin{array}{r}\text { Water-Table } \\
\text { Elevation, } \\
\text { ft above MSL } \\
\end{array}$ & $\begin{array}{r}\text { Water-Table } \\
\text { Elevation, } \\
\text { m above MSL }\end{array}$ \\
\hline $\begin{array}{l}299-E 25-32 P \\
699-39-39 \\
699-40-33 A \\
699-40-39 \\
699-41-40 \\
699-42-40 B \\
699-43-41 E \\
699-43-42 J \\
699-43-43 \\
699-43-45 \\
699-44-42 \\
699-44-43 B \\
699-45-42 \\
699-47-35 A \\
699-47-46 A\end{array}$ & $\begin{array}{l}06 / 13 / 91 \\
06 / 13 / 91 \\
06 / 07 / 91 \\
06 / 13 / 91 \\
06 / 13 / 91 \\
06 / 07 / 91 \\
06 / 13 / 91 \\
06 / 13 / 91 \\
06 / 13 / 91 \\
06 / 13 / 91 \\
06 / 13 / 91 \\
06 / 13 / 91 \\
06 / 07 / 91 \\
06 / 07 / 91 \\
06 / 07 / 91\end{array}$ & $\begin{array}{l}670.04 \\
536.65 \\
518.05 \\
541.84 \\
545.94 \\
546.46 \\
550.86 \\
581.68 \\
579.37 \\
597.68 \\
579.22 \\
580.12 \\
577.33 \\
476.36 \\
580.14\end{array}$ & $\begin{array}{l}266.12 \\
123.78 \\
107.04 \\
128.39 \\
129.56 \\
123.83 \\
129.38 \\
162.37 \\
164.20 \\
192.91 \\
158.29 \\
164.48 \\
160.23 \\
62.43 \\
175.62\end{array}$ & $\begin{array}{l}403.92 \\
412.87 \\
411.01 \\
413.45 \\
416.38 \\
422.63 \\
421.48 \\
419.31 \\
415.17 \\
404.77 \\
420.93 \\
415.64 \\
417.10 \\
413.93 \\
404.52\end{array}$ & $\begin{array}{l}123.11 \\
125.84 \\
125.28 \\
126.02 \\
126.91 \\
128.82 \\
128.47 \\
127.81 \\
126.54 \\
123.37 \\
128.30 \\
126.69 \\
127.13 \\
126.17 \\
123.30\end{array}$ \\
\hline
\end{tabular}

(a) MSL = mean sea level. 
IABLE C.2. Decommissioned 216-U-Pond Water-Level Measurements in Unconfined Aquifer Wells, June 1991 (measured by Westinhouse Hanford Company)

\begin{tabular}{|c|c|c|c|c|c|}
\hline Well & Date & $\begin{array}{c}\text { Casing } \\
\text { Elevation } \\
\text { ft above MSL (a) } \\
\end{array}$ & $\begin{array}{l}\text { Depth to } \\
\text { Water, } \\
\mathrm{ft} \\
\end{array}$ & $\begin{array}{r}\text { Water-Table } \\
\text { Elevation, } \\
\text { ft ábove MSL } \\
\end{array}$ & $\begin{array}{r}\text { Water-Table } \\
\text { Elevation, } \\
\text { mabove MSL } \\
\end{array}$ \\
\hline $\begin{array}{l}299-W 10-05 \\
299-W 10-13 \\
299-W 11-10 \\
299-W 15-04 \\
299-W 15-15 \\
299-W 15-16 \\
299-W 18-15 \\
299-W 18-21 \\
299-W 19-01 \\
299-W 19-04 \\
299-W 19-14 \\
299-W 21-01 \\
299-W 22-07 \\
299-W 23-11 \\
699-32-70 B \\
699-32-72 \\
699-32-77 \\
699-35-78 A \\
699-37-82 A \\
699-38-70 \\
699-39-79\end{array}$ & $\begin{array}{l}06 / 04 / 91 \\
06 / 14 / 91 \\
06 / 04 / 91 \\
06 / 04 / 91 \\
06 / 07 / 91 \\
06 / 07 / 91 \\
06 / 04 / 91 \\
06 / 07 / 91 \\
06 / 05 / 91 \\
06 / 07 / 91 \\
06 / 05 / 91 \\
06 / 07 / 91 \\
06 / 07 / 91 \\
06 / 07 / 91 \\
06 / 19 / 91 \\
06 / 19 / 91 \\
06 / 19 / 91 \\
06 / 19 / 91 \\
06 / 19 / 91 \\
06 / 19 / 91 \\
06 / 04 / 91\end{array}$ & $\begin{array}{l}672.31 \\
699.04 \\
728.89 \\
662.00 \\
697.96 \\
684.89 \\
660.76 \\
668.62 \\
673.77 \\
715.26 \\
693.21 \\
699.26 \\
687.41 \\
664.14 \\
666.68 \\
668.16 \\
653.74 \\
660.65 \\
636.75 \\
710.67 \\
673.52\end{array}$ & $\begin{array}{l}207.38 \\
234.62 \\
273.22 \\
194.95 \\
231.44 \\
217.64 \\
192.99 \\
201.81 \\
204.44 \\
256.24 \\
230.08 \\
244.48 \\
228.41 \\
199.42 \\
215.54 \\
214.87 \\
192.66 \\
194.89 \\
169.85 \\
257.99 \\
207.15\end{array}$ & $\begin{array}{l}464.93 \\
464.42 \\
455.67 \\
467.05 \\
466.52 \\
467.25 \\
467.77 \\
466.81 \\
469.33 \\
459.02 \\
463.13 \\
454.78 \\
459.00 \\
464.72 \\
451.14 \\
453.29 \\
461.08 \\
465.76 \\
466.90 \\
452.68 \\
466.37\end{array}$ & $\begin{array}{l}141.71 \\
141.56 \\
138.89 \\
142.36 \\
142.20 \\
142.42 \\
142.58 \\
142.28 \\
143.05 \\
139.91 \\
141.16 \\
138.62 \\
139.90 \\
141.65 \\
137.51 \\
138.16 \\
140.54 \\
141.96 \\
142.31 \\
137.98 \\
142.15\end{array}$ \\
\hline
\end{tabular}

(a) MSL = mean sea level. 
TABLE $\dot{C} .3 .1100$ and 3000 Areas Water-Level Measurements in Unconfined Aquifer Wells, June 1991 (measured by Westinghouse Hanford Company except as noted)

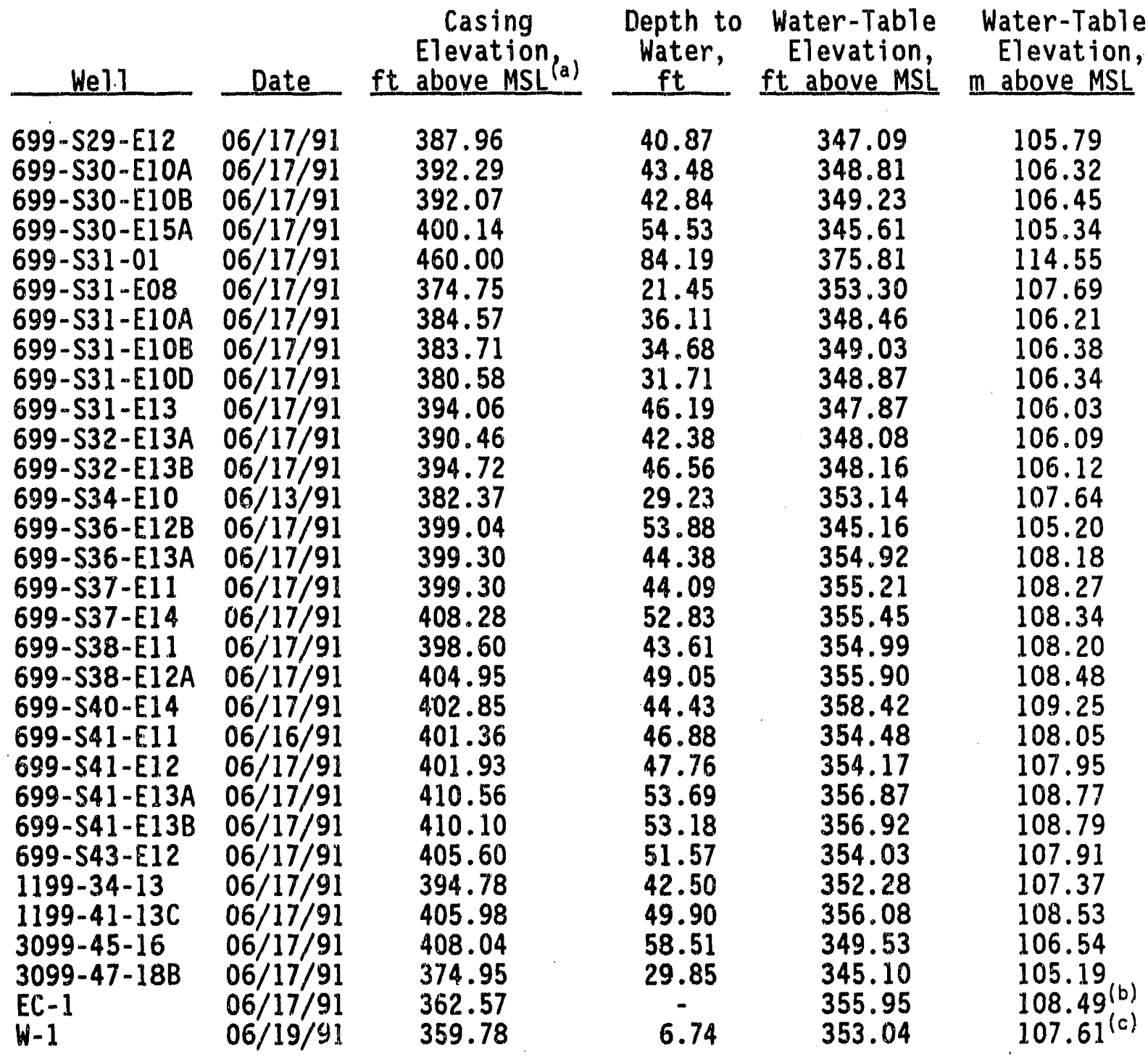
(a) $M S L=$ mean sea level.
(b) Measured by PNL with a float recorder.
(c) Measured by PNL. 
TABLE C.4. 100-N Ared Water-Level Measurements in Unconfined Aquifer We1ls, June 1991 (measured by Westinghouse Hanford Company)

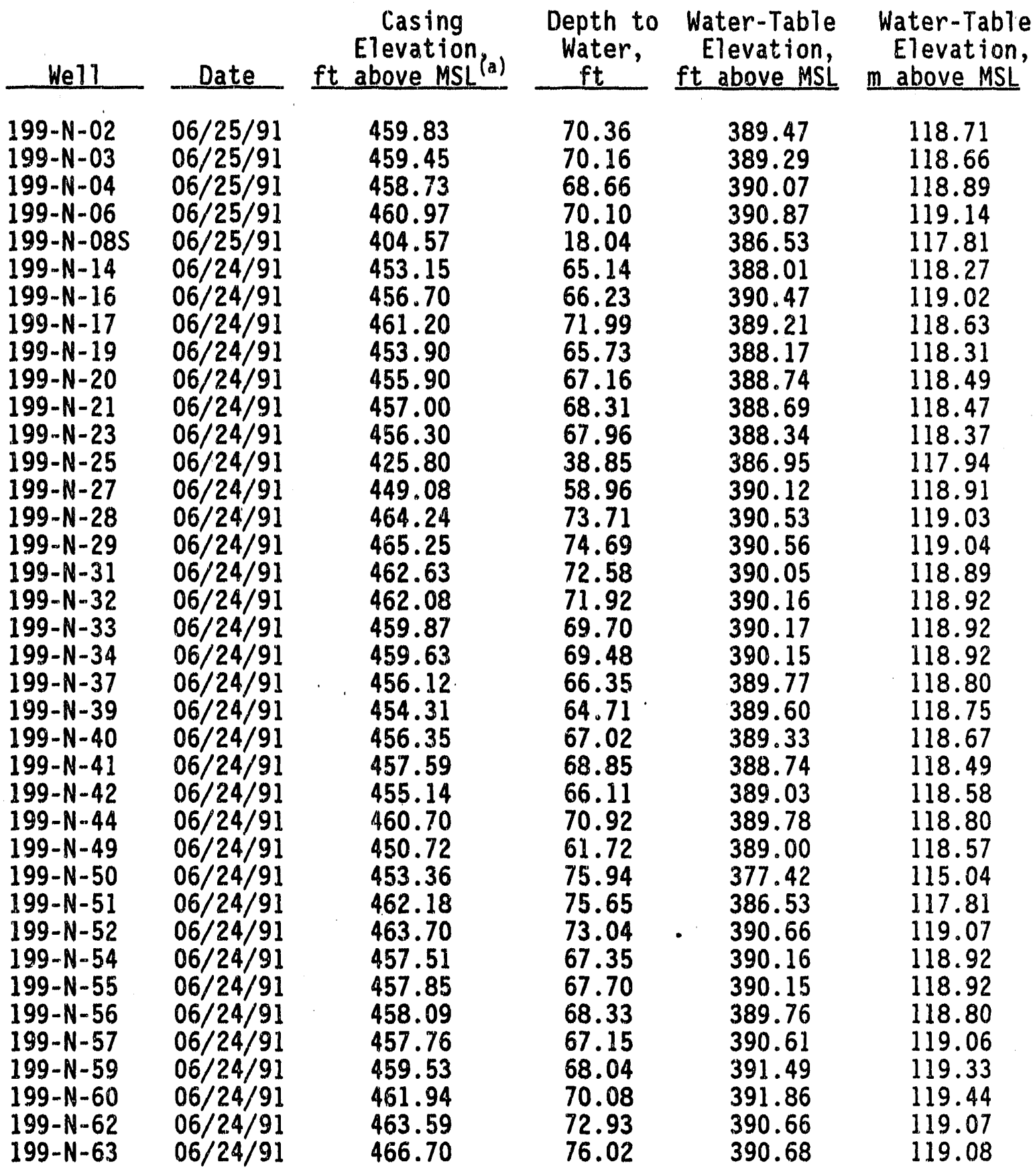

(a) MSL = mean sea level. 
TABLE C.4. (contd)

Casing
Elevation to Water-Table Water-Table
Water, Elevation,

$\begin{array}{llllll}199-N-64 & 06 / 25 / 91 & 454.63 & 64.00 & 390.63 & 119.06 \\ 199-N-65 & 06 / 25 / 91 & 456.44 & 66.14 & 390.30 & 118.96 \\ 199-N-66 & 05 / 25 / 91 & 465.25 & 75.20 & 390.05 & 118.89 \\ 199-N-67 & 06 / 25 / 91 & 458.46 & 69.29 & 389.17 & 118.62 \\ \text { HGP (B) } & 06 / 24 / 91 & & & 386.90 & 117.93\end{array}$

(a) MSL m mean sea level.

(b) Hanford Generating Plant (River Stage Elevation). 
TABLE C.5. 300-Area Water-Level Measurements in Unconfined Aquifer Wells, June 1991 (measured by Westinghouse Hanford Company)

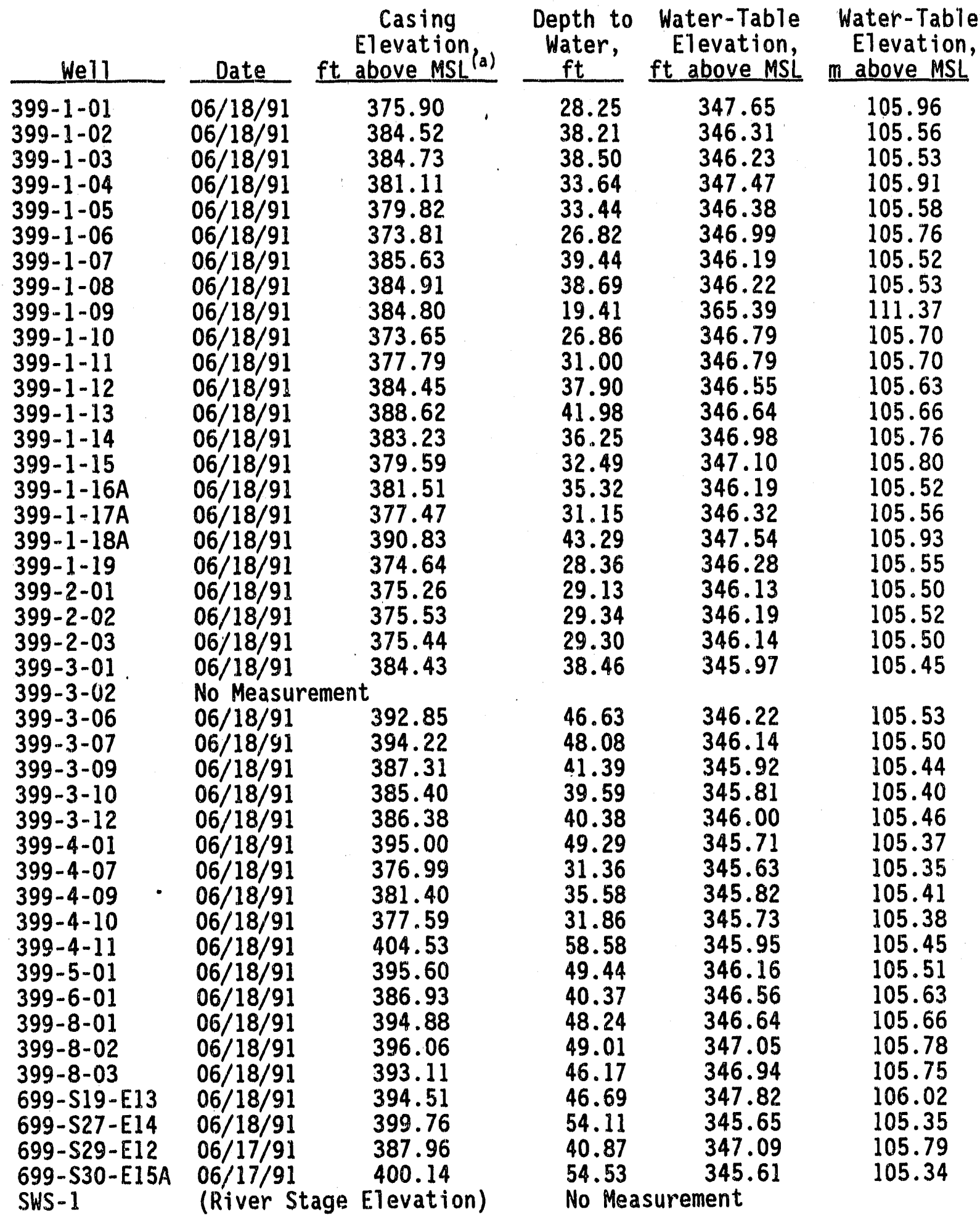

(a) $M S L=$ mean sea level. 


\section{DISTRIBUTION}

No. of

Copies

\section{OFFSITE}

2 DOE/Office of Scientific and Technical Information

\section{ONSITE}

23. DOE Richland Field Office

G. M. BelT

R. D. Hildebrand

R. G. Holt

M. W. Tiernan (20)

17 Westinghouse Hanford Company
M. R. Adams
L. C. Brown
G. D. Carpenter
M. A. Christie
C. D. Delaney
L. P. Diedicker
J. J. Dorian
K. R. Fecht
K. A. Gano
E. M. Greager
R. L. Jackson
G. L. Kasza
A. G. Law
D. L. Lund
J. A. Serkowski
L. C. Swanson
Public Reading Room

54 Pacific Northwest Laboratory

D. J. Bates

J. V. Borghese
No. of

Copies

R. W. Bryce

M. A. Chamness

J. C. Evans

M. D. Freshley (Mark)

R. M. Fruland

T. J. Gilmore

S. M. Goodwin

W. R. Gorst

R. H. Gray (2)

J. M. Hales

S. H. Hall

P. E. Long

S. P. Luttrel1

J. P. McDonald

R. W. Netson

D. R. Newcomer (20)

W. T. Pennell

K. D. Pohlod

J. T. Rieger

L. E. Rogers

R. Schalla

S. S. Teel

P. D. Thorne

R. W. Wallace

E. J. Westergard Publishing Coordination Technical Report Files (5)

Routing

R. M. Ecker

J. W. Falco

M. J. Graham

P. M. Irving

R. L. Skaggs

P. C. Hays (1ast) 


\section{Plate 1. Hanford Site and Outlying}

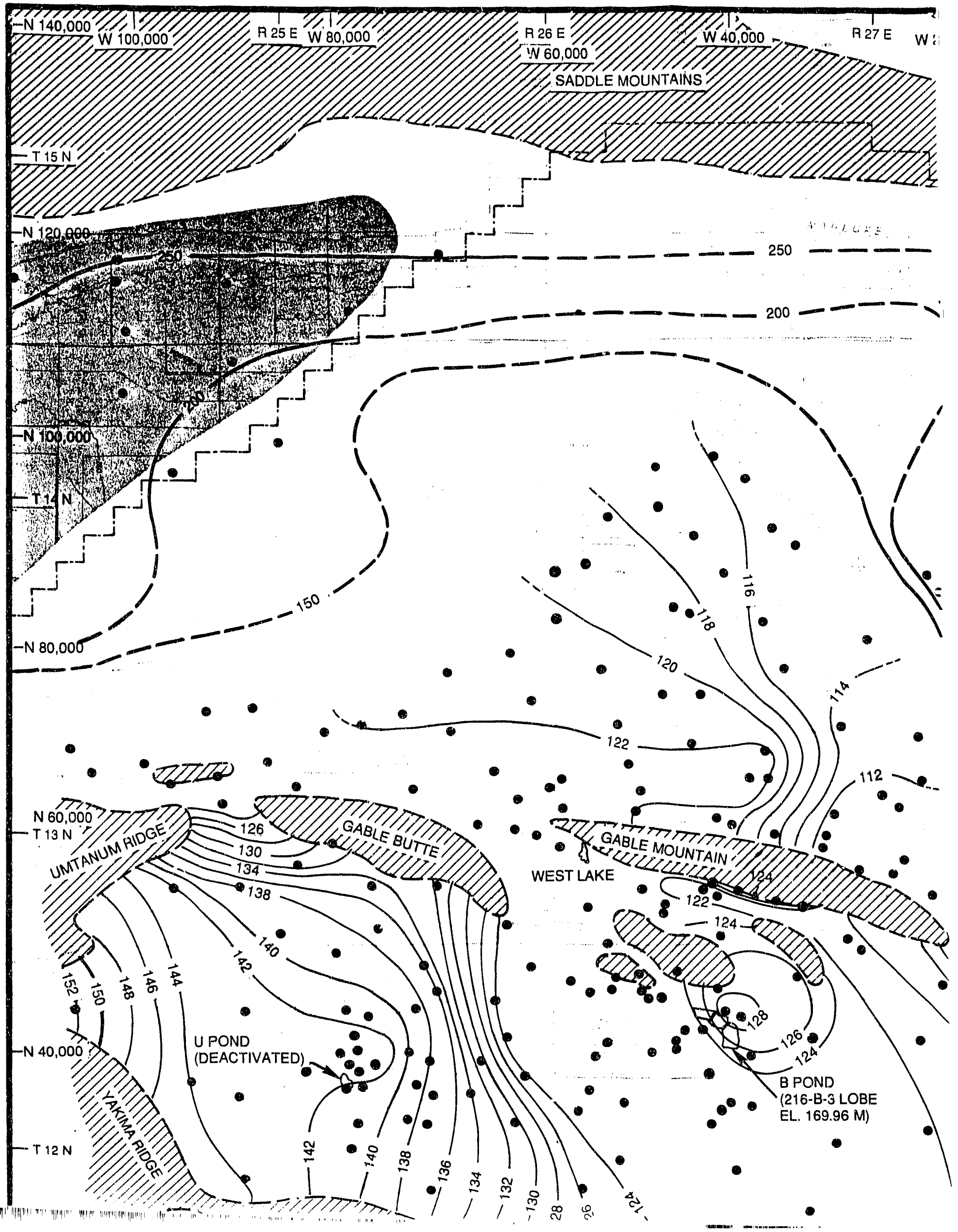




\section{tlying Areas Water-Table Map}

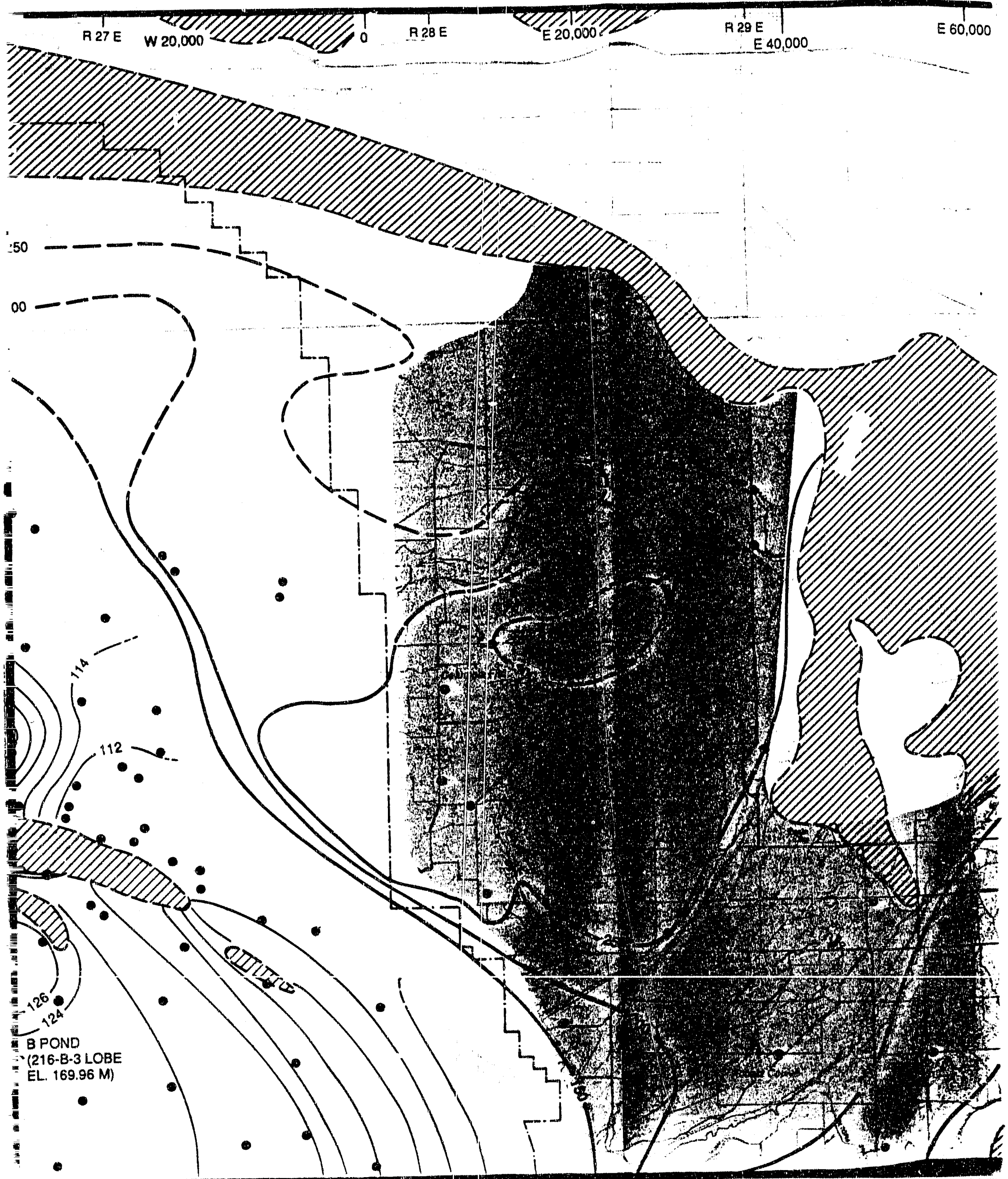




\section{2as Water-Table Map June-August 1991}

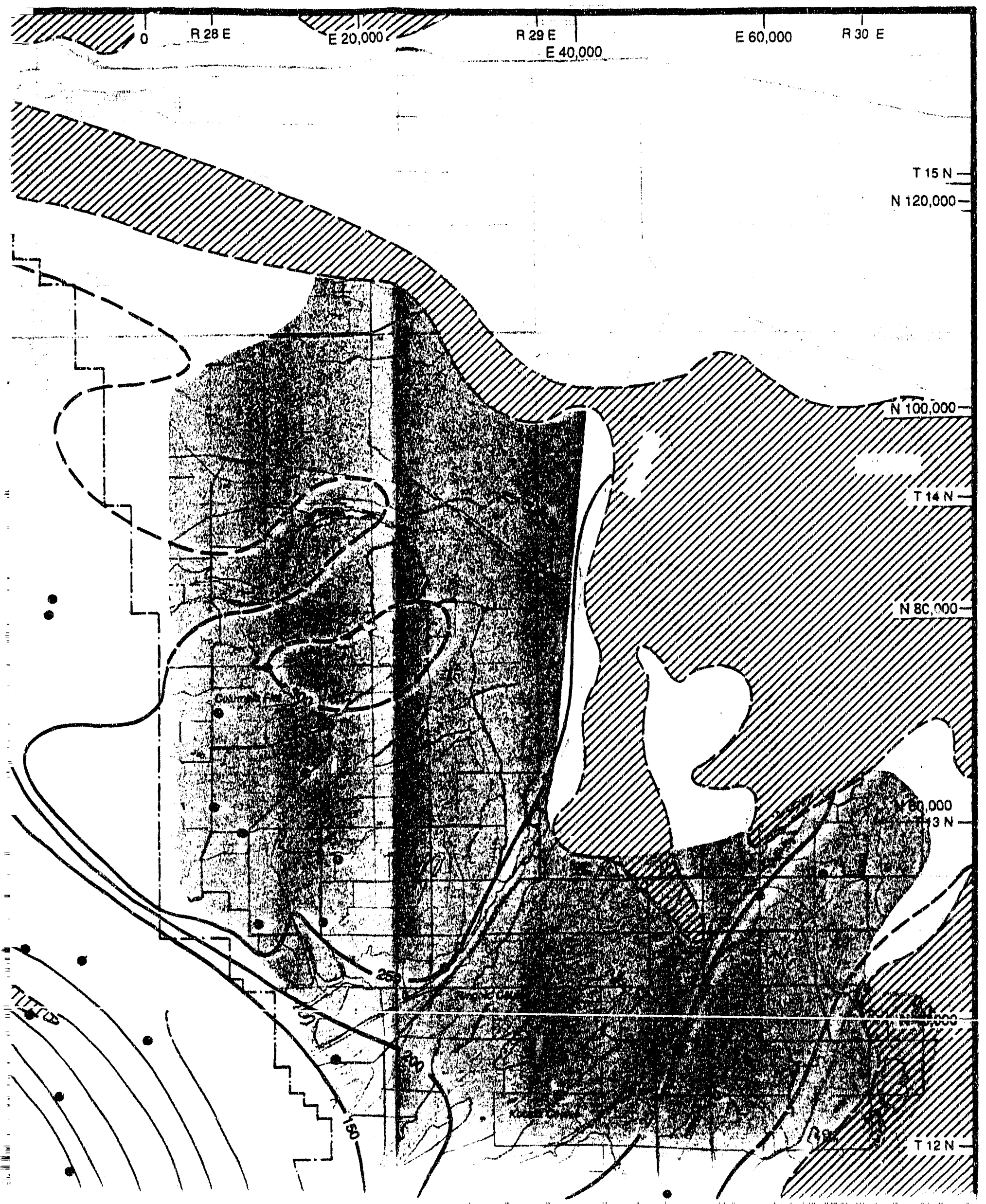




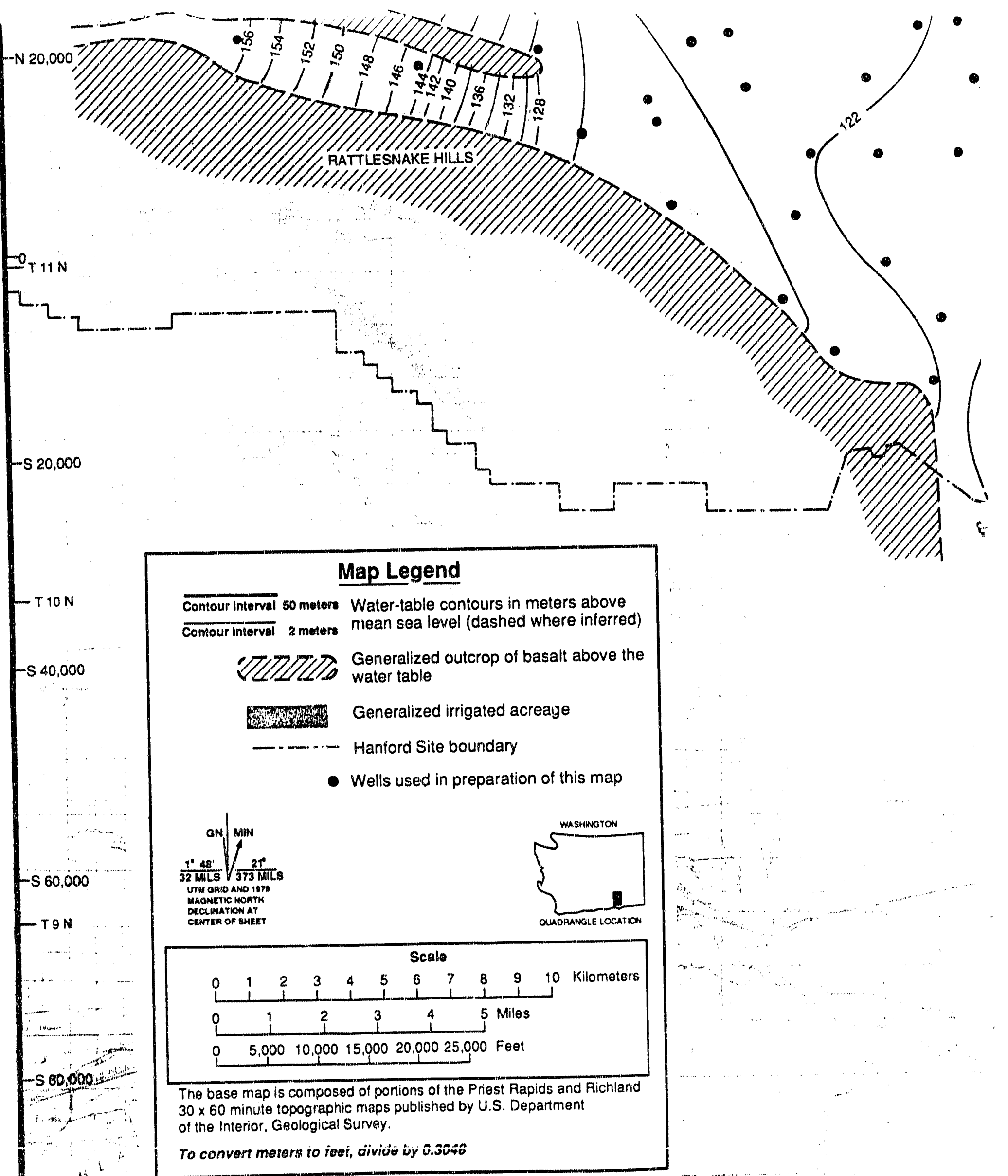




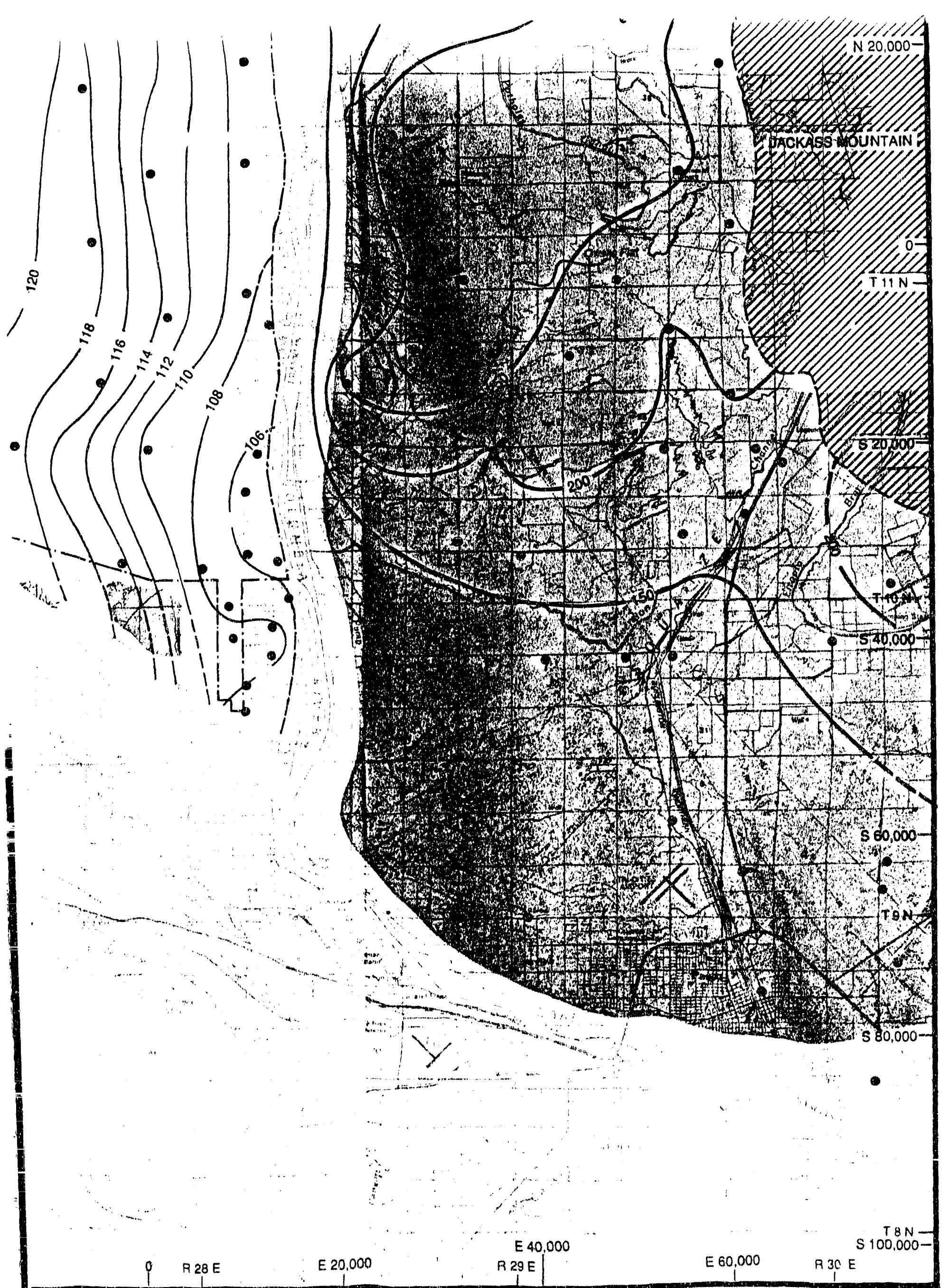



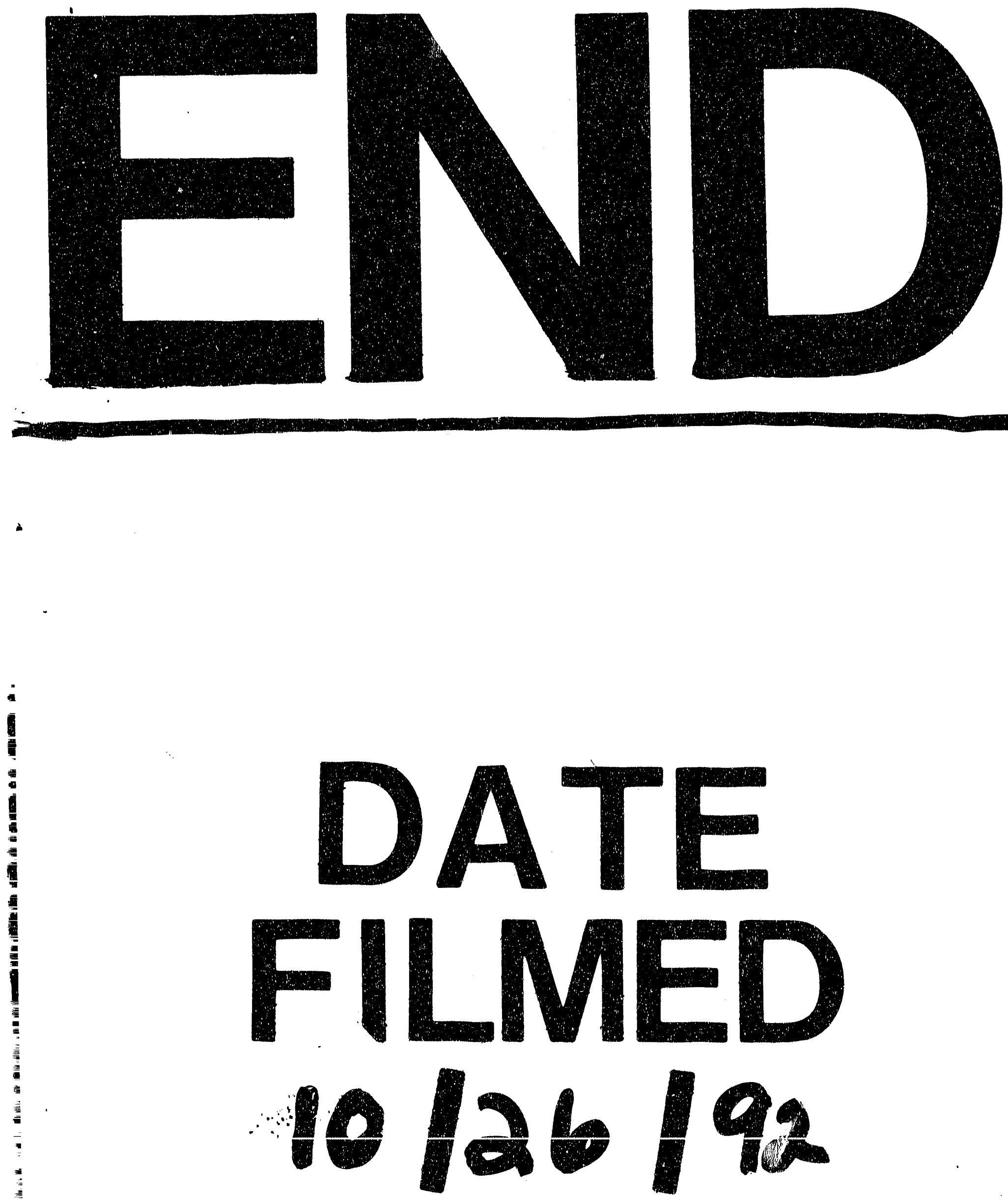


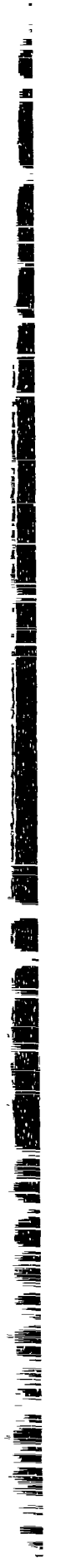

